
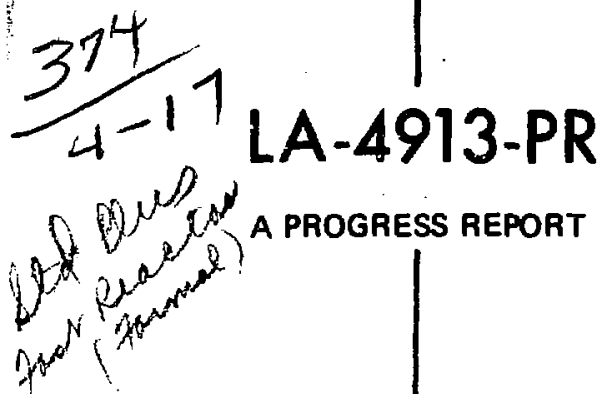

\title{
A PROGRESS REPORT
}

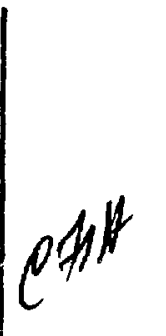

Quarterly Status Report on the

\section{Advanced Plutonium Fuels Program}

October 1 to December 31, 1971

\author{
October 1 to Docomber 31,1971
}


This report was prepared as an account of work sponsored by the United States Government. Neither the United States nor the United States Atomic Energy Commission, nor any of their employees, nor any of their contractors, subcontractors, or their employees, makes any warranty, express or implied, or assumes any legal liability or responsibility for the accuracy, completeness or usefulness of any information, apparatus, product or process disclosed, or represents thas its use would not infringe privately owned rights.

This report presents the status of the LASL Advanced Plutonium Fuels program. The four most recent reports in this series, all unclassified, are:
LA-4546-MS
LA-4693-MS
LA-4595-MS
LA-4749-MS

In the interest of prompt distribution, this progress report was not edited by the Technical Information staff

Printed in the United States of Amarica. Available from National Technical Information Service

U. S. Department of Commerce

5285 Port Royal Road

Springfield, Virginia 22151

Price: Printed Copy \$3.00; Microfiche \$0.95 
LA-4913-PR

A Progress Report

UC-80 and

FAST REACTOR REPORT

SPECIAL DISTRIBUTION

ISSUED: March 1972

\section{sclentitic laboratory \\ of the University of Californie \\ LOS ALAMOS, NEW MEXICO 87544}

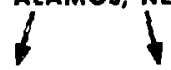

\section{Quarterly Status Report on the Advanced Plutonium Fuels Program October 1 to December 31, 1971}

Compiled by

R. D. Baker

NOTICE

This ropost we prepired is an account of work eponiored by the Unitod States Government. Nother the Uniced Sintes zur the United States Atomic Enerzy Commintop, nor sny of their employeas, nor any of their contriactors, subcontinctor, or thots omployes, males ariy wurnaty, expries or implied, or emumas any leinl linbility or respontbility for the eccuracy, complotenetis of uefulnes of any information; apperatus, product or procen dieclosed, or ropresints that ite we product or procen dieclosed, or roptesints
would not infriage priptoly owned sights. 
FOREWORD

This is the 22nd quarterly report on the Advanced Plutonium Fuels Program at the Los Alamos Scientific Laboratory.

Most of the investigations discussed here are of the continuing type. Results and conclusions described may therefore be changed or augmented as the work continues.

Published reference to results cited in this report should not be made without obtaining explicit permiseion to do so from the person in charge of the work. 


\section{TABLE OF CONTENTS}

I. Introduction

II. Equipment Development

III. Hot Cell Facility at DF Wegt

IV. Method of Analysis

v. Requests from DRDT

I. Introduction

II. Irradiation Testing

III. Fuel Property Measurements

IV. Publications

V. References

I. Introduction

II. Analytical Chemistry Program for Boron Carbide

III. Analytical Cheisistry Program for LMFBR/FFTF Fuel

IV. Papers Presented at Meetings

V. References 


\section{EXAMINATION OF FAST REACTOR FUEIS}

$\begin{array}{ll}\text { Person in Chkirge: } & \text { R. D. Baker } \\ \text { Principal Investigators: } & \text { J. W. Schulte } \\ & \text { K. A. Johnson } \\ & \text { G. R. Waterbury }\end{array}$

\section{INTRODUCTION}

This project is directed toward the examination and comparison of the effects of neutron irradiation on LMFBR Program fuel materials. Uairradiated and irradiated materials will be examined as requested by the Fuels and Materials Branch of DFDT. Capabllities are established and are being expanded for providing conventional preirradiation and postirradiation examinations. Nondestructive tests will be conducted in a hot cell facility specifically modified for examining irradiated prototype fuel pins at a rate commensurate with schedules established by DRDT.

Characterization of unirradiated and irradiated fuels by analytical chemistry methods will continue, and additional methods will be modified and mechanized for hot cell application. Macro- and micro-examinations will be made on fuel and cladding using the shielded electron microprobe, emissiun spectrograph, radiuchemistry, gamma scanner, mass spectrometers, and other analytical facilities. New capabilities will be developed in: gamma scanning, anelyses to assess spatial distributions of fuel and fission products, mass spectrometric measurements of burnup and fission gas constituents, chemical analyses, and measurernent of carbon in irradiazied fuels.

Microstructural analyses of unirradiated and irradiated materials will continue using optical and electron microscopy, and autoradiographic and $x$-ray techniques. Special emphasis will be placed on numerical representation of microstructures and its relationship to fabrication and irradiation parameters. New etching and mounting techniques will be developed for high burnup materials. II. EQUTPMENT DEVELOPMENT

A. Inert Atmosphere Systems (P. A. Mason, R. F. Velkinburg)

1. Disassembly Cell

The atmosphere was purified during the report period b/ a recirculating system which maintained impurity levels at 3 to $15 \mathrm{ppm} \mathrm{O}_{2}$ and 1 to $5 \mathrm{ppm} \mathrm{H}_{2} \mathrm{O}$. The cell was placed on an Ar once-through purge for the week end of December 4 duriny a scheduled power outage. The concentrations of impurities were less than $25 \mathrm{ppm} \mathrm{O}_{2}$ and $5 \mathrm{ppm} \mathrm{O}_{2}$ during the outage.

\section{Metallography Cells}

The atmosphere was maintained in the two metallograpny cells by an Ar once-through purge pending installation of the butyl acetate removal system and replacement of the KBM oxygen catalyst tanks. Typical impurity levels have been reduced during the report period from maxima of $650 \mathrm{ppm} \mathrm{O}_{2}$ and $50 \mathrm{ppm} \mathrm{H}_{2} \mathrm{O}$ to $50 \mathrm{ppm} \mathrm{O}_{2}$ and $15 \mathrm{ppm}$ $\mathrm{H}_{2} \mathrm{O}$.

An experimental PVC manipulator boot with a polyurethane exterior coating was supplied by a Plastics Group at LASL. The boot was installed on December 1 in an effort to determine the resistance to the butyl acetate vapors present in the metallography cells. An exposure of at least three or four months will be required to determine the efficacy of the coating.

A study was made of the fersibility of converting the $d r y$ inert atmosphere in the metallography cells to a 
dry air atmosphere. If the recirculating purifier systems were used for the control of the $\mathrm{H}_{2} \mathrm{O}$ concentration, very little additional effort $0 z$ cost would be required to also maintain a low concentration of $\mathrm{O}_{2}$. The use of air for the makeup gas for the alpha box pressure differential control system would not be satisfactory as it would quickly saturate the purifier with moisture. Converting from an Ar atmosphere to one of $\mathrm{N}_{2}$ would be feasible, although a somewhat higher level of moisture would be present in the cell due to higher levels of moisture in the $\mathrm{N}_{2}$ supply gas. The lower price for $\mathrm{N}_{2}$ would result in a 70$80 \%$ reduction in costs for the present makeup gas. Similar savirgs would be obtained by converting from an $\mathrm{Ar}$ once-through purge to a $\mathrm{N}_{2}$ purge. No changes would be required in the design or operation of the inert cells due to the conversion to $\mathrm{N}_{2}$.

B. Master-Slave Manipulator Maintenance

(P. A. Mason, O. Serna, R. F. Velkinburg)

The establishment of a routine inspection and maintenance program appears necessary to assure that the master-slave manipulators provide continuing service. The frequency of breakdowns has been steadily increasing since the curtailmert of manipulator maintenance and repair by specialized parsonnel. Certain operating personneI have recently been designated to develop experience in this area since 22 pairs of manipulator arms ( 3 different types) are in constant service, and 8 pair are avajlable as spares.

A list of repair parts required to maintain the new CRL Model "L" MSMs was prepared for procurement.

\section{Shipping Casks}

The second cask (DOT SP-5885) for off-site shipping of 40-inch-long fuel pins was received in mid-November.

The small cask, designed to ship small sections of fuel pins off-site, will be available by about February 1, 1972.

A request was initiated recently to use a third "Rover-type" cask for the LASL operations. A survey of the operations indicates that the two casks currently on hand satisfy only the storage requirements at the Wing 9 Facllity and the transfer between the DP West and Wing 9 sacilities; the third cask would be available for off-site
The difficulties encountered with a contaminated Rover cask being shipped from Idaho to Hanford resulted in the temporary withdrawal of the DOT approval of these casks. Minor design corrections have been submitted for approval to DOT through the AEC Albuquerque Operations Office. It is hoped to have the casks reinstated to service by about February 10. LASL will be responsible for making the necessary corrections to the casks as required.

D. New Metallograph Blister

(D. D. Jeffries, K. A. Johnson, C. D.

Montgomery, J. M. Ledbetter, T. Romanik,

R. F. Velkinburg, J. B. Weber)

The alpha containment box and modular shield components were sand blasted and painted. The 14-in. thick modules were filled with $\mathrm{Pb}$ shot and the 9 in.-thick ones with $\mathrm{Pb}$ bricks.

A final test set-up is being made, and appropriate coupling plates have been attached to insure proper orientation during re-assembly. The new Mini-Manipulators were installed and checked out for operations and coverage. A modification was made to the light well to render it essentially flush with the top of the box. Items remaining to be completed are:

1. Shop fabrication of the new gate valve connecting the box to the tunnel system.

2. Detailed design and fabrication of shield door for the bag-out port in the old metallograph shield module.

3. Shop fabrication of a new telescoping type mechanism for the bag-out port.

It is expected that these three items will be completed by February 1.

\section{E. New Mechanical Frofilometer}

(M. E. Lazarus, C. D. Montgomery, T. Romanilk)

An equipment search is being made to find a 4-jaw scroll type chuck which will meet the precision requirements of the new profilometer design. The diameter sensing units (LVDT'B) will be mounted on the jaws of the chuck. This profilometer will be used as a back-up unit and also for obtaining diameters of breached pins.

\section{F. Butyl Acetate Removal System}

(G. S. Dow, M. E. Lazarus)

Design, fabrication, and procurement of 
components for the equipment to remove butyi acetate (used in metallography operations) from the inert gas systems are proceeding.

\section{G. High Pressure Metallographic Sample Potting} System

(C. D. Montgonery, T. Romanik, D. S. Shaffer)

Fabrication of a prototype pressure potting vessel was completed. The vessel was hydrostatically tested to $5200 \mathrm{psi}$. The test set-up, which has been approved by a responsible I $\Lambda$ SL Safety Engineer, is in use in betagamma cells. The samples prepared thus far have given encouraging results.

H. Cask Insert Elevator

(C. D. Montgomery, T. Romanik, J. M. Ledbetter, R. F. Velkinburg)

Fabrication, assembly, and check-out of a 20c-1bcapacity electro-mechanival elevator for use in the Rover type shipping casks have been completed. This remotely operated device has improved the transfer operations considerably.

I. Bausch \& Lomb Optical Read-out Gacge (M. E. Lazarus, T. Romanik, J. R. Trujillo)

$A$ new design for modification of the $B$ and $L$ gauge has been completed and submitted to the shope for fabrication. This design incorporates a system for adjusting the position of even a severely bowed fuel element so thiat its axis is perpendicular to the measuring anvils at the point of measurement. It is hoped that this improvement will permit the safe use of this equipment on badly bowed pins. J. Radiography Cask

A preliminary study has been made of the requirements for a new radiography aask capable of handing fuel pins up to $61 \mathrm{in.}$ long and with burnups as high as 10 at.\%. It is proposed that depleted uranium be used for shielding. Additional shielding would be provided to accommodate the fueled section of the pin.

Since the cask will be 8 in. higher than the one currently in use, a hole will be drilled in the Betatron room in front of the machine to provide for the increased helght. This increased height will pose no special handling problems at the two hot cell facilities or with the existing truck.

Detail design of the final system is expected to begin about the middle of January.

\section{K. Scanning Electron Microscopy}

(K. A. Johnson, J. L. Lehmann)

The shielded transpolt cask and sample holder for Irradieted samples have been fabricated and are now being checked. In addition, specimen procedures and shielding for the electron microscope are being developed.

\section{Microstructural Analysis Equipment and}

\section{Developments}

(R. J. Beckman, J. H. Bender, K. A. Johnson,

J. L. Lehmann, L. W. ReeBe, K. L. Walters)

1. The prototype ion gun etcher has been fabricated, assembled, and is in operation. Operating peraneters for the best metallographic etching of materials are being determined.

2. A computer code IMAGE VI has been written and made fully operational. This code is on pormfile and can be easily used from cur remote terminal. This daia reciuctíñin añ interpretation code for image analysis contains plotting routines for our output which can also be used at our remote terwinal.

3. The prototype high pressure impregnation system is being fabricated. Components for in-cell system are being procured.

4. The new electric stage for the $B$ and $L$ remote metallograph is being shipped to LASL.

5. Installation engineering drawings for the high speed photographic printer are in process.

6. A jet washer for in-cell metallographic speciment is being designed.

7. The theoretical study on the measurement of randomly shaped volumes in space is continuing. Preliminary results indicate that significant applications to microsiructural image analyigis will result from this study.

8. Upgrading electronics have been ordered for both the SEM and the SEM-EDX units.

9. Pattern recognition modules have been ordered for the Image Analysis Computers.

11. HOT CELL FACILTY AT DPWEST

(F. J, Fitzgibbon, M. E Lazarus o M:

Ledbetter, C. D. Montgomery, Jo Phillips

J. R. Trujillo, R. Fir Vellkinburg)

\section{A. Structure and Equipment:}

Enclosure of the balcony has been completed and 
the air conditioning equipment has been moved into place. The plumbing and electrical work will be completed when craftemen are available.

\section{B. Hot Cell Equipment}

\section{Gamma Scanning Equipnient}

All of the lead-tungsten collimators have been poured and radiographed; seven of the eight units have been acceptable. The eighth unit was poured when potentially troublesome voids were observed. This last unit has been recently submitted for a adiography. Installation of gamma scanning equipment in the cells will start in January.

\section{Electro-Optical Profilometer}

The pexiscope shlelding has been designed and fabrication started.

A design has been submitted for a series of profulometer standards which should cover a wide range of fuel element diameters. Safety switches are presently being added to the mechanical stage to prevent damage in case of operator error.

\section{Macro-Camera System}

The Macro-Camera system has been installed, and the electrical wiring of this system is now being completed. Due to limited space at the face of this cell the camera stand is being modified to allow easy removal and precise replacement.

\section{Pulsed Eddy Current Scanner}

Components for the vertical drive mechanism for this device have been procured. A suitable four channel recorder with amplifiers and pre-amplifiers has been ordered.

\section{METHODS OF ANALYSIS}

A. Measurement of $\mathrm{U}$ and $\mathrm{Pu}$

(J. W. Dahlby, C. S. MacDougall, G. R. Waterbury)

Measurement of $U$ and Pu without chemical separation by controlled potential coulometry is satisfactory for fuels having undergone as much as 6 at. \% burnup. The Pu content is obtained from the integrated current required to either oxidize $\mathrm{Pu}(\mathrm{III})$ to (IV), or to reduce $\mathrm{Pu}$ (IV) to (III) at a Ft electrode. The U content is calculated from the net integrated current required to reduce U(VI) to (IV) at a Hg electrode. At burnups above 6 at.\% the direct coulometric titrations are not sufficiently precise because of side reactions caused by the extremely high radioactivity of the large quantities of fission product elements. For this reason, methods are being investigated for quantitatively separating $\mathrm{U}$ and $\mathrm{Pu}$ from these fission products.

Initial effort was devoted to precipitation separations because of their simplicity, speed, and minimal requirements for manipulations, It was found that precipitation of some fission products as insoluble fluorides while $U$ and Pu were oxidized to their soluble (VI) oxidation states greatly reduced the radioactivity, and the recoveries of $U$ and $P u$ were no less than $99.8 \%$. To complete the removal of fission products, the Pu and $U$ were then reduced t $n$ their (III) and (IV) oxidation states, respectively, and precipitated as insoluble fluorides, leaving the fluoride-soluble fission products in solution. Satisfactory recovery of $\mathrm{Pu}$ resulted, but about $1 \%$ of the $U$ was lost. As a 99\% recovery wais not considered adequate, hydroxide precipitation was tried for separating the $U$. First the $U$ was precipitated in the absence of complexing agents to separate it from hydroxide-soluble fission products. Less than $0.1 \%$ of the $U$ was lost in this step. To improve the separation factor, selective precipitation of the hydroxide-insoluble fission product elements while $\mathrm{U}(\mathrm{VI})$ is complexed with carbonate is now being studied.

\section{B. Determination of $\mathrm{C}$ and $\mathrm{H}$}

(T. K. Marshall, G. R. Waterbury)

Carbon and $H$ are impurities that affect the irradiation behavior and the effective reactor lifetimes of cladding and fuel materials. Reliable measurements of these elements, therefore, are necessary in evaluating these effects. One well-tested determination of $\mathbf{C}$ and $\mathbf{H}$ consists of burning the sample in pure $\mathrm{O}_{2}$ at $1000^{\circ} \mathrm{C}$ to convert these impurities to $\mathrm{CO}_{2}$ and $\mathrm{H}_{2} \mathrm{O}$ which are trapped and weighed. Equipment previously installed in a hot cell for these measurements was tested initially by analyzing standard samples containing known percent amounts of $\mathrm{C}$ and $\mathrm{H}$. Recoveries of $\mathrm{C}$ and $\mathrm{H}$ were approximately $100 \%$, and the relative standard reviation of a single measurement was $2 \%$.

Further tests consisted of analyses of five different stafnless steel claddings from fuel pins having 
undergone 3 to 8 at. $\%$ burnup. The results ranged from $<70 \mathrm{ppm}$ to $1600 \mathrm{pprn}$ for $\mathrm{C}$ and $<28$ to $230 \mathrm{ppm}$ for $\mathrm{H}$. Then three mixed oxide fuels from the same fuel pins were analyzed with results ranging between $<20$ and 370 ppm for $C$ and < 10 to $153 \mathrm{ppm}$ for $H$. The precision $(1 \sigma)$ of repeated measurements on each fuel or cladding sample was within the expected limits of the method ( $\pm 10 \mathrm{ppm}$ or $\pm 2 \%$, whichever is larger).

Analyses of $\mathrm{PuC}$ and (UPu)C for $\mathrm{C}$ and $\mathrm{H}$ are planned to evaluate the method for measuring $C$ at contents of approximately $5 \%$. Modifications of a LECO Low Carbon Analyzer fos hot cell use are in process to provide additional capabilities and higher temperature combustions. C. Gamma scanning

(J. R. Phillips)

The quantitative determination of gamma-emitting fission products is dependent on detector efficiency which must be measured as a function of gamma-ray energy. An energy callbration of one detector was completed using two sets of IAEA standards. The detector's efficiency increased exponentially in the energy range from $2 \mathrm{MeV}$ to about $122 \mathrm{KeV}$ where an anomalous reduction in the efficlency occurred. As the standards do not have gammarays in this energy range, a ${ }^{75}$ Se source with gammo energies of $97 \mathrm{KeV}, 121 \mathrm{KeV}, 136 \mathrm{KeV}, 265 \mathrm{KeV}, 280$ $\mathrm{KeV}$, and $401 \mathrm{KeV}$ was used. The peak areas were normalized to superimpose on the callbration curve in an attampt to obtain additional data points. The results indicated that the published values for the decay yields of ${ }^{75}$ Se are incorrect. Other sources are being sought to complete the calibration of the detector.

A computer code, COLLIM, was developed to simulate the beam shaping by various collimator systems, and the calculated beam shapings for several systems were compared to the experimentally determined beam shapes. The calculated beam shape compares favorably with the experimeatal result for a 0,500-in. callimating slit. The results for the $0.020-i n$. collimator are difficult to interpret because significant mechanical distortions were introduced in the collimator during the fabrication process. The COLLIM code will be used to evaluate the collimators being fabricated for installation at DP site.

Various parameters in the code will be changed to determine the optimum collimator design.

V. REQUESTS FROM DRDT

\section{A. Examination of Unirradiated Fuels (C. W. Bjorklund, E. A. Hakkdla, K. A. Johnson)}

Westinghouse ARD: Electron microprobe, x-ray, and optical microscopy examinations have been completed on ten samples from WARD, and the final report is in preparation,

\section{B. Examination of Irradiated Material}

R. M. Abernathey, K. A. Johnson, E. D. Loughran, R. A. Morris, J. R. Phillips, J. W. Schulte, G. R. Waterbury, W. F. Zelezny)

General Electria Company: Melting point determinations of the irradiated mixed oxide fuel spectmens are being periformed. Details of the examination are reported under the Project 463 "Fuel Pxoperties" section of this report.

Some cladding sections from these specimens are being prepared for axygen and carbon measurements using equipment in the hot cells.

Gulf United Nuclear Fuels Corporation: Tests performed on Gulf United materials are described below.

Gamma scanning was applied to the non-destructive examination of the six following fuel pins shown in the table on the following page.

TABLE 401-1

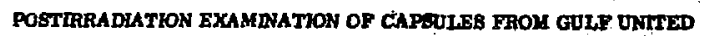

Examination

2. Rectography

3. Photograpky (Full Lergth)

4. Cover Gas SampHing

E. Cover Gus Analyouls

6. Na and Cled Removal
1. Micrometer Measurement

unc coneraldentit $192,197,196,200,206,208$ 185, 197, $198,200,206,208$ 187, 189, 101, 102, 194, 196 : $197,198,200,206,208$ : $187,189,191,192,194,195$ $197,198,200$, 206, 208 187, 189, 191, 192, 194, 105, $197,198,200,200,208$ $187,189,191,192,195,197$, 198, 206, 208

Wa meltinc and cled removil on UNC-19s and -200 will be portormed in an

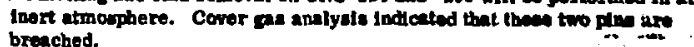


TABLE 401-II

POSTIRRADIATION EXAMINATION OF PRN FROM GULF UNITED

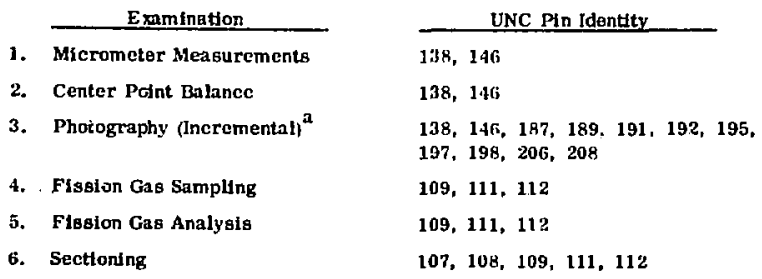

a Photography of the breached UNC -194 and -200 pins will be performed in an inert atmosphere box following removal of the capsule cladding.

TABLE 401-III

GAMMA SCANS OF UNC FUEL PLNS

\begin{tabular}{lcc} 
& \multicolumn{2}{c}{ Number of Gamma Scans } \\
\cline { 2 - 3 } Fuel Pin Number & Grosg & Complete Spectral \\
\cline { 2 - 2 } & 4 & 2 \\
UNC-197 & 8 & 2 \\
UNC-198 & 4 & 2 \\
UNC-200 & 4 & 1 \\
UNC-206 & 7 & 1 \\
UNC-208 & 4 & 1
\end{tabular}

In addition, the fission products on a suspected crack from the pin surface of UNC-194 were identified by analyzing contamination wiped from the surface with tissues (swipes).

A cross section sample from UNC-219, which cuntained a U-Pu carbide fuel and had exceeded its melting point in places, was examined using the shielded electron microprobe.

Flux monitor wires from UNC-96, -99 , and -104 , were analyzed radiochemically for ${ }^{54} \mathrm{Mn}$.

Microstructural examinations have been completed on five specimens, each, from UNC-92, $-96,-99$, and -104. The examinations in argon atmosphere included macrophotography, alpha and beta-gamma autoradiography and optical microscopy (including mosaics).

Microstructural examinations are in progress on
UNC $-107,-108,-109,-111$, and -112 .

Four specimens were prepared for the shielded electron microprobe. This included pre- and post-EMX photomicroscopy.

Nuclear Materials and Equpment Corporation: Examinations made on NUMEC materials are described in Table 401-IV.

Four gross gamma scans and one completed spectral scan were made on NUMEC-A-1 to determine which end of the fuel pin contained $\mathrm{UO}_{2}$ pellets and which end contained $\mathrm{UO}_{2}-\mathrm{PuO}_{2}$ pellets.

Special optical microscopy was completed on several samples from A-10 and A-11.

Four samples were prepared for the shielded electron microprobe. This included pre- and post-EMX photomicroseopy.

Cross section samples of NUMEC-A-10A, NUMEC$A-10 \mathrm{H}$, NUMEC-A-11F, and NUMEC-B-11 were examined with the shielded electron microprobe.

Burnup analysis was performed on one sample from NUMEC A-5.

A 2-inch section of NUMEC pin A-1 containing the $\mathrm{WO}_{2}^{-}$ (UPu) ${ }_{2}$ interface was shipped to ANL on November 3 , 1971. On November 10,1971 , twelve sections of fuelcladding and 3 sections of cladding were shipped to ORNL. These sections were removed from NUMEC pins B-1, $A-5, A-6, A-8, A-9, A-10$, and $A-11$.

WADCO Corporation: Two pins from the PNL series were received on December 2, 1971 from WADCO. Examinations made on these two pins during this period are tabulated in Table 401-V.

TABLE 401-IV

POSTIRRADLATION EXAMINATION OF NUMEC MATERLAL
Examination

1. Fission Gas Sampling

2. Fission Gas Analysis

3. Sectioning
NUMEC PIn Identlity

$A-1, A-6$

$A-1, A-6$

$A-1, A-6, A-10$ 
TABLE 401-V

POSTIRRADIATION EXAMINATION OF WADCO MATERLAL

\begin{tabular}{ll} 
1. Visual Inspection & PNL PIn Identity \\
\cline { 2 - 2 } 2. Preliminary Measurement & $17-7,17-33$ \\
3. Photography (Full Length) & $17-7,17-33$ \\
4. Radlography & $17-7,17-33$ \\
5. Gamma Scanning & $17-7,17-33$ \\
6. Removal of Wire Wrap & $17-7^{\mathrm{a}}, 17-33^{\mathrm{b}}$ \\
7. Photography (Incremental) & $17-33$ \\
\end{tabular}

$a_{4}$ gross and 1 complete spectral analysis

${ }_{4}$ gross and 3 complete spectral analyees

The fission gas sampling and profilometry tests will be completed by January 15, at which time a sectioning diagram will be prepared by WADCO to designate the samples for destructive examination.

Material from Other Experimenters

Additional discussions have been held with $\mathrm{GE}$ personnel relative to the examinations to be performed on 5 pins to be shipped to LASL in January 197 ?.

Plans have been made to provide the cask for bringing the ORNL pin, irradiated in ETR, to LASL for examination in February or March. Details of the examination and priority scheduling are yet to be discussed with DRDT and ORNL. 


\section{PROJECT 463}

\section{CERAMIC PLUTONIUM FUEL MATERIALS}

Person In Charge: K.D. Baker

Principal Invegtigator: J. L. Green

\section{INTRODUCTION}

The primary objective of this program is the overall evaluation of the most promfsing of the candidate fuel systems for advanced LMFBR application. Emphasis currently is placed on the study of the relative merits of stainless steel clad nitride and carbide fuels under conditions that appropriately exploit the potential of these materials to cperate to high burnup at high power densiHes. The major portion of the program is the evaluation of the irradiation performance of these fuel element systems. A continuing series of irradiation experiments is being carried out under steady state conditions in fast reactor enviromments to assess the effects of damage and burnup on stainless steel clad, carbide and uitride fuel elements. These experiments are designed to investigate fuel swelling, interactlons between the fuel and clad and thermal bonding medium, fission gas release, and the migration of fuel material and fission products as a function of burnup and irradietion conditions. In addition, experiments are being designed to allow the study of the effects of rapid, overpower, reactor transients on carbide and nitride fuel assemblies. Contiguous efforts are necessary in the development of fuel material preparation and fabrication procedures as well as the techniques required for the characterization of fuel materials both before and after irradiation.
A second objective in the program is the determination of thermophysical, mechanical and chemical properHes and characteristics of plutonium-containing ceramics that are required for their evaluation and use as fuel materials. A broad range of capabilities in this area bas been developed, Including the study of (1) phase relationships using differential thermal analysis, (2) thermal transport, (3) thermal stability and compatibility, (4) hot hardness and its temperature dependence, (5) structure and phase relationships using high tomperature $x$-ray and neutron diffractlon, (6) thermal expansion, and (7) compressive creep rates as a function of temperature and stress. Several of these techniques are available for use with irraditat fuels.

\section{IRRADIATION TESTING}

The objective of the irradiation testing program is the overall evaluation of the most promising of the candidate fuel systems for advanced LMFBR application. The Irradiation experiments are carried out under conditions that take advantase of the potential of these materials to operate to high burnup at high power densities.

\section{A. Fuel Synthesis and Fabrication}

(K. W. R. Johnson, M. W. Shupe, C. Baker, H. Moore, R. Walker, C. W. Bjorklund) 
TABLE 463-I

\section{CARBIDE FUEL FOR REPLACEMENT PINS}

\begin{tabular}{|c|c|c|}
\hline & Specification & Fuel $^{a}$ \\
\hline Length (in.) & $0.250 \pm 0.010$ & $0.253 \pm 0.004$ \\
\hline Diameter (In.) & $0.260 \pm 0.002$ & $0.260 \pm 0.002$ \\
\hline Density (\% Theor.) & $95 \pm 2$ & $93.1 \pm 0.1$ \\
\hline $\mathrm{O}_{2}+\mathrm{N}_{2}(\mathrm{ppm})$ & $\leqq 800$ & $609 \pm 92$ \\
\hline Metallic impurities (ppm) & low & $194 \pm 39$ \\
\hline Inclusions (volume \%) & $<0.5$ & $\leqq 0.02$ \\
\hline Higher carbides & $\mathrm{ND}^{\mathrm{b}}$ & ND \\
\hline Radiographic defects & ND & ND \\
\hline Volatile gases (ppm) & low & $<1$ \\
\hline Fuel pin pellets per pin & 54 & 54 \\
\hline $\begin{array}{l}\text { Archivel pellets per pin } \\
\text { a Average of } 4 \text { batch prep }\end{array}$ & attons & 12 \\
\hline
\end{tabular}

\section{Carbide Production}

The conditions necessary for routine production of cartide fuel for current EBR-II irradiation tests were developed in a serles of preparations using existing equipment. Subsequent emphasis was placed on the production of carbide pellets for 4 Series 3 replacement pins. Fuel for each pin was prepared as a single batch of pellets in sufficient quantity to allow for characterization and archival specimens. Shown in Table 463-I is a comparison of the fuel characterization with the fuel specifications. In addition to fuel for replacement pins, comparable material was produced for loading 2 archival pins. Efforts are now being directed toward production of carbide fuel for the carbide-nitride 19-pin subassembly.

\section{Equipment Development}

The installation of a high-temperature tungsten mesh furnace in a new recirculating iriert atnosphere giove box was completed. Trial runs with stacked empty cruclbles were made by heating the furnace to $2000^{\circ} \mathrm{C}$ in $\mathrm{Ar}$, He, high vacuum and partial atmospheres of $\mathrm{Ar}$.
Acquisition of the equipment for a new hydrogen treatment facility was completed and should be installed in the near future. The facility incorporates high and ul tra-high vacuum components, a $\mathrm{Pd}$ alloy $\mathrm{H}_{2}$ diffusion purification unit, and programmed temperature control. Furnaces and furnace tubes are interchangeable with components for a nitride synthesis facility.

A recirculating inert atmosphere glove box was transferred from another LOB Alamos site to the DF Plutonium Facility. This glove box will incorporate facilities for powder processing nitride fuels. Design of this unit was completed and components for a hydride-nitride furnace were acquired.

Equipment was designed and fabricated which will increase the scale of carbothermic reductions to $120 \mathrm{~g}$ per preparation.

Equipment and techniques are being developed and refined for gas chromatographic analysis of the effluent gas stream from the hydrogen reduction furnaces used to adjust the carbon content of carbide fuel materials. The procedure is being used both as a process control analysis and also to provide more basic information on the carbide- $\mathrm{H}_{2}-\mathrm{CH}_{4}$ reaction. Preliminary testing has demonstrated the applicability of the chromatographic techniques for following the reaction and determining end points of the reduction; in addition, the equipment has been shown to be very useful for monlbring the nitrogen contamination levels in high purity Ar inert atmospheres.

\section{Nitride Pollet Eyaluation}

The nitricie fuel for the initial loading of the IASL carbide-nitride subassembly will be provided by Battelle Memorial Institute, Columbus:' None of the fuel material has been recelved, to date, but a small number of chemlcally typical, solid solution, nitride fuel pellets have been recelved for preliminary evaluation. They were recelved, unpackaged, inspected, and sampled for the following:

1. chemical analysis

2. spectrochemical analysis

3. determination of density

4. metallographic examination

5. $x$-ray powder difraction andyals. 
TABLE $100-\pi$

\section{CHEMICAL ANALYBI OF NTRRE PELLETI}

\begin{tabular}{|c|c|c|c|c|}
\hline Bample No. & \multicolumn{3}{|c|}{ (conementration lon $=(\%)$} & Calouleted Formula \\
\hline & $\underline{\underline{\mathbf{U}}}$ & Pu & 프 & \\
\hline 6 & 78.6 & 18.29 & 5.36 & $\left(U_{0.11}, P u_{t}+20\right) N_{0.10}$ \\
\hline 11 & 76.6 & 18.29 & 4.87 & 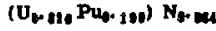 \\
\hline 12 & 76.1 & 18.45 & 5.30 & 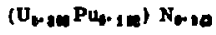 \\
\hline 20 & 76.1 & 18. 41 & 4.68 & 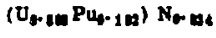 \\
\hline Hinc. & - & - & 6.26 & - \\
\hline
\end{tabular}

Approximately 14 pellets were received, but the exact number is undefined because most of the pellets were fractured. The largest chunks were identified by numbering, and kept separate during the sampling procedue.

The results of chemical analysis for major constituents of 4 pellets are shown in Table 463-II.

The stoichlometry of the nitride is somewhat lower than expected, typical being $\mathrm{MN}_{0.95}$ for the solid solution nitride.

\section{TABLE 463-ПI}

\section{CHEMICAL ANALXSIS OF NITRDE PELLETS ${ }^{2, b}$}

(concentrations in ppm)

$\begin{array}{lrlr}\mathbf{O} & 545 & \mathrm{Cr} & <10 \\ \mathrm{C} & \mathbf{5 0 5} & \mathrm{Mn} & <5 \\ \mathrm{Th} & \mathbf{1 0} & \mathrm{Fe} & 20 \\ \mathrm{LI} & <1 & \mathrm{NI} & <10 \\ \mathrm{Be} & <1 & \mathrm{Cu} & <2 \\ \mathrm{~B} & <1 & \mathrm{Zn} & <20 \\ \mathrm{Na} & 8 & \mathrm{Sr} & <5 \\ \mathrm{Mg} & <5 & \mathrm{Cd} & <20 \\ \mathrm{Al} & <10 & \mathrm{Sn} & <5 \\ \mathrm{SI} & <20 & \mathrm{~Pb} & <5 \\ \mathrm{Ca} & <5 & \mathrm{BI} & <2\end{array}$

a Results for $\mathrm{O}, \mathrm{C}$, and Th are the average for four samples for chemical analysis.

b Results for all others are the average for three samples for spectrochemical analysis.
The results of chemical analyses for minor contaminants are shown in Table 463-III. The $O$ and Th concentrations are nominal, but the $\mathrm{C}$ content is somewhat higher then normal for the industry. Resulte of spectrochemical analysis indicate that the cationic impurity levels are quite low.

The densittes of several pellets were determined by immersion techniques. The results shown in Table 463-IV indicate densities that are generally betwsen 93 and 94\% of theoretical. The anamolous density of sample 2 is probably due to a large, closed, internal void and does not reflect the microscopic density of the material. Lattice dimensions of several samples were determined using Debye-Scherrer powder techniques and were found to be $4.8930 \pm 0.0005 \mathrm{~A}$.

\section{TABLE 463-IV}

\section{NITRIDE PELLET DENSITLES}

\begin{tabular}{ccc} 
Sample & $\begin{array}{c}\text { Density } \\
\left(\mathrm{g} / \mathrm{cm}^{3}\right)\end{array}$ & o.T.D. \\
\hline 1 & 13.36 & 93.2 \\
2 & 12.70 & 88.6 \\
7 & 13.45 & 93.9 \\
9 & 13.51 & 94.3 \\
10 & 13.48 & 94.0
\end{tabular}

a Theoretical density $=14.33 \mathrm{~g} / \mathrm{cm}^{3}$

The metallographic examination of 5 samples is complete. Generally, the microstructures were found to be single phase with $\leq 0.5$ vol $\%$ of a white appearing second phase in evidence. The "white phase" may be slightly more concentrated toward the pellet exteriors. The grain size is approximately twice as large near the pellet centers as near the edge. The pellet edges are composed of very small sized grains as compared to the centers. The pores or votds are of two general types:

a. large irregularly shaped pores located at or near grain triple points

b. by comparison, very small sized pores located in the grain interior. 
One pellet was beated in Ar to approximately $1600^{\circ} \mathrm{C}$, and then examined for possible microstructural changes. No changes were found.

\section{Process Development}

The basic carbothermic reduction process that is being developed for carbide production has been described previously. ${ }^{1}$ Analysis showed the stock plutonium axide used in the initial experiments to have a composition corresponding to $\mathrm{PuO}_{2} \cdot \mathrm{C}_{0.05}$. This was due to the presence of unconverted oxalate. A fraction of the stock oxdde was reignited in air, and then used for further experiments. A mixture of uranium and plutonium dioxides and carbon was made to contain $12.18 \mathrm{wt}$ \% $\mathrm{C}$. At equilibrium after reaction, a carbon to metal ratio of 1. 1 would be expected. After a heat treatment similar to that used in earlier experiments, the reacted mass was found to be essentlally single phase by metallographic exarination. The chemical formula, as calculated from chemical analyses, was $\left(\mathrm{U}_{0.801} \mathrm{Pu}_{0.199}\right) \mathrm{C}_{0.998} \mathrm{O}_{0.008}$. First, the $U / \mathrm{Pu}$ ratio remained essentially the same as the starting ratio indicating that the oxide proportions in the starting blend can be set to correspond to the desired final composition. Second, the $C / M$ ratio in the product is slightly lower than the target, io., excess carbon was not present, and the oxygen concentration is slightly high as a consequence. The composition of the mixture of oxides and carbon can be adjusted to yield an increased $C / M$ ratio sufficient to result in a product with a lower oxygen content.

A scoping test of compatibility between the reaction products and tungsten was completed. An oxdde compact was reacted in close proximitry to a tungsten crucible. The carbide was found to contain an insignificant amount of $W, 20 \mathrm{ppm}$, and the crucible was visually unchanged. Thermodynamic calculation predict acceptable compatiblitity between the $\mathrm{CO}$ gas and tungsten. This permits the scheduling of a tungsten mesh furnace to be used for further development of the process.

\section{B. EBR-II Irradiation Testing}

(J. O. Barner, L. L. Marriott, H. E. Strohm) The purpose of the EBR-II ir radiations is the evaluation of high performance fuel element systems for application in advanced LMFBR reactors. Over the last few years, in addition to the LOB Alamos Scientific Laboratory (LASL), Gulf United Nuclear Fuels CorporaHon (GUNFC), Battelle Memorial Institute (BMI), and Oak Ridge National I Jaboratory (ORNL) have had development programs concerned with the irradiation of advanced fuels. Presently, all of these programs are being consolidated at LASL. The responsibiltty for experiments degigned by GUNF'C that are currently in EBR-II or are partially evaluated has been transferred to LASL. A similar transfer of responstbility for BMI and ORNL experiments is currently in progress. The status of experiments originated by GUNFC and of experiments originated by LASL is included in this report. The status of expertments originated by BMI and ORNL will be reported in future LASI, status reports as the responsibility for these programs is transferred.

Four serles of LASL-originated experiments are planned. The status of the three series for which approval-In-principle has been recelved frcm the AEC is described in Table 463-V. All these experiments use encapsulated fuel elements.

The fourth series is composed of nineteen singily clad fuel elements. Approximately one half of the elements will contain carbide fuel, while the remainder will contain nitride fuel. The rentative description for these experiments is shown in Table 463-VI. The test variables include fuel type, cladding cold-work, smear density, heating rate, operating temperature, and burnup. The fuel used in the fabrication of these elements will be $95 \%$ dense, single-phase $\left(\mathrm{U}_{0.8} \mathrm{Pu}_{0.2}\right) \mathrm{C}$ or $\left(\mathrm{U}_{0.8} \mathrm{Pu}_{0.2}\right) \mathrm{N}$. The carbide fuel will be fabricated from materlal synthesized using both arc-melting and carbothermic reduction processes. The nltride fuel for the initial loading will be supplied by Battelle Memorial Institute and will be prepared using the hyoride-nitride process. The cladding tubing will be Type 316 stainless steel 0.310 in. O.D. with 0.012 in. walls. The cladding for the tests has been ordered through WADCO from Superior Tube Co. Delivery is behind schedule, but is anticipated in mid-February, 1572. The cladding will comply, as nearly as is currently available, to thefuel element cladding epecification 
TABLE $463-\mathrm{V}$

SERIES 1,2, AND 3 EXPERIMENTS

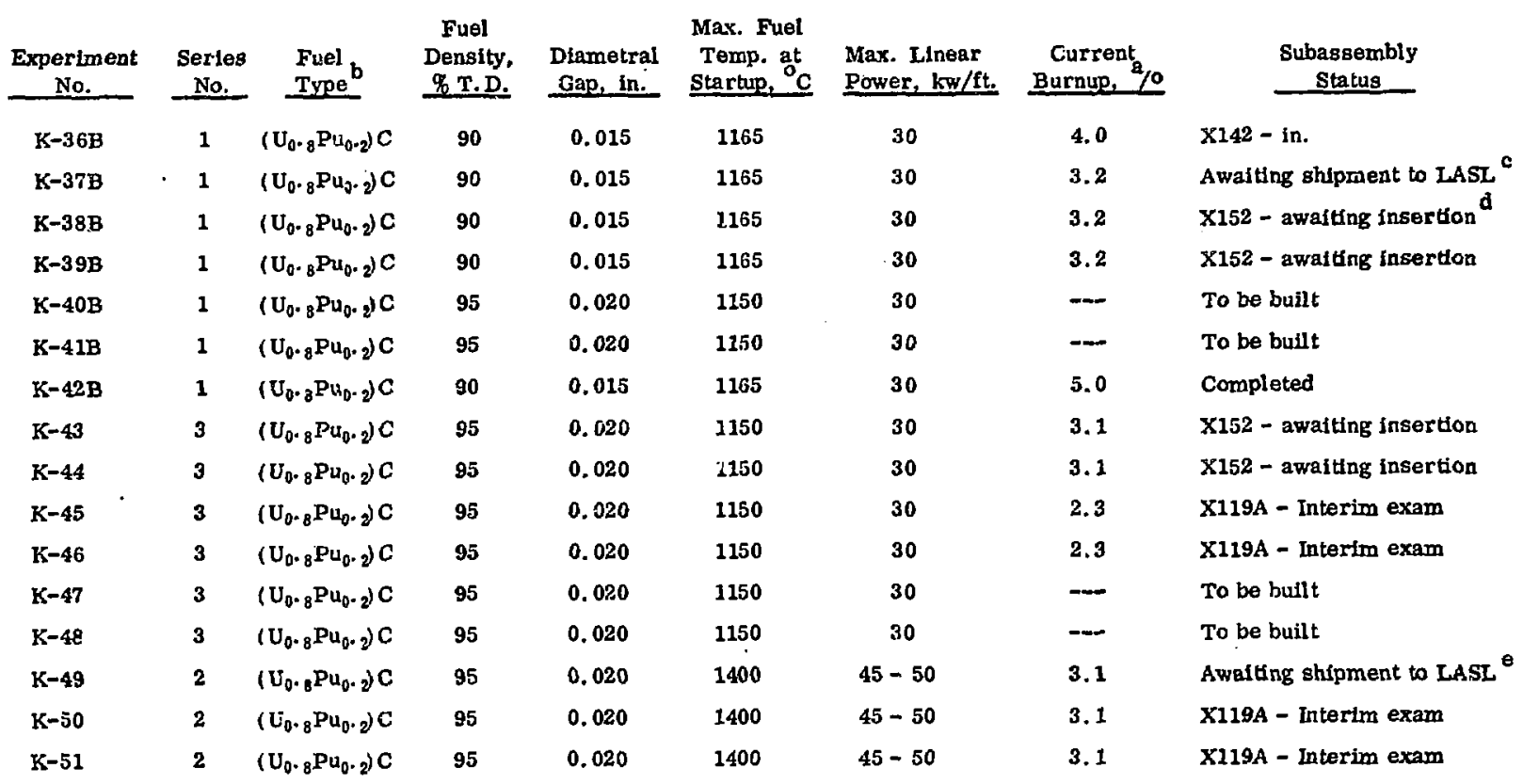

a. All elements are clad in 0.300 in. $0 . d$. $\times 0.280$ in. i. d. Type 316Ss. All are sodium bonded elements.

b. The Series 1 and 3 experiments are fully enriched in ${ }^{23} \mathrm{U}$. The series 2 experiments contain $97 \%{ }^{233} \mathrm{U}$. All fuel is single-phase.

c. Capsule $\mathrm{K}-37 \mathrm{~B}$ was damaged during reconstitution of X152 to such an extent that it can not be irradiated further.

d. Capsule K-38B was damaged during reconstitution of X152 at EBR-II. Further irra-'ition is planned.

e. Capsule K-49 will be destructively examined at the request of the EBR-II Project.

ruthengen

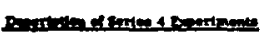

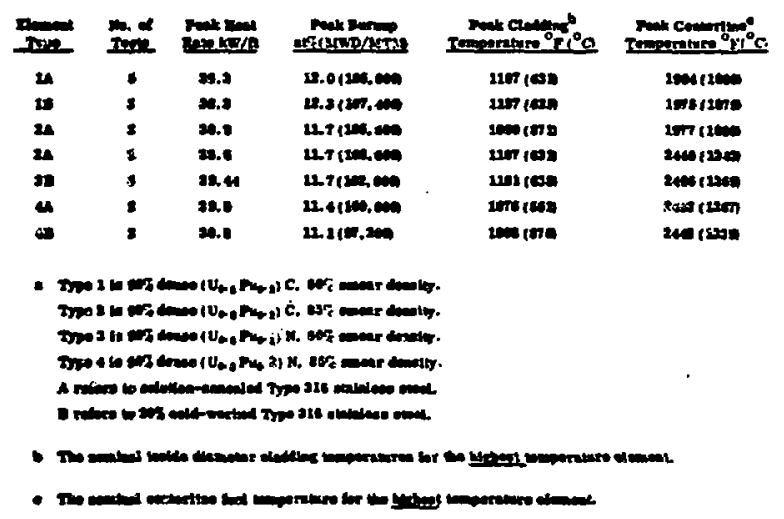

RDT-E-13-8T. Final design of this subassembly is awaiting approval-in-principle from the AEC and design data for the new EBR-II configuration including the stainless steel reflector.

One of the primary purposes of the Series 4 subassembly is to provide data for a critlcal comparison of the overall irradiation behavior of carbide and nitride fuel elements which have been irradiated under conditions that are, as nearly as possible, identical.

The status of the experiments originated by GUNFC for which responsibility has been transferred is summarized in Tables 463-VII, VII, $X$, and X. A total of 42 elements are efther in EBR-II or avallable for insertion. Eleven elements are in the process of destructive examInation. Twenty-two elements are awaiting shipment to EBR-II. The latter group will first be shipped to LASL 


\section{TABLE 463-VII}

TA8K $\mathbf{1 3 0 0}$

EBR-II MRADUATION EXPERDUENTS

\begin{tabular}{|c|c|c|c|c|c|c|c|c|c|c|}
\hline $\begin{array}{c}\text { Experiment } \\
\text { No. } \\
\end{array}$ & $\begin{array}{l}\text { Fitul } \\
\text { Treen }\end{array}$ & $\begin{array}{l}\text { Fuel } \\
\text { Denolty } \\
\text { \&.T.D. }\end{array}$ & $\begin{array}{l}\text { Cled } \\
\text { Material }\end{array}$ & $\begin{array}{c}\text { Cled } \\
\text { Thlolenexs. } \\
\text { In. }\end{array}$ & $\begin{array}{l}\text { Dinmetral } \\
\text { Gap in. }\end{array}$ & 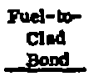 & $\begin{array}{l}\text { Hex. Fual } \\
\text { Temp. ot } \\
\text { startape o }\end{array}$ & $\begin{array}{l}\text { Mnx. Whens } \\
\text { Poner, } \\
\text { Lo/A } \\
\end{array}$ & 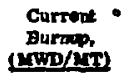 & $\begin{array}{c}\text { sobuesembly } \\
\text { sinted }\end{array}$ \\
\hline U:3 & $\mathrm{MC}+5 \% \mathrm{M}_{2} \mathrm{C}_{2}$ & B4 & 31688 & 0.000 & 0.004 & H० & 2750 & 18.0 & 92,000 & $x 142-i=$ \\
\hline U94 & $\mathrm{MC}+5 \% \mathrm{OM}_{2} \mathrm{C}_{3}$ & 84 & 32658 & 0.013 & 0.007 & He & 1060 & 11.8 & 84,000 & X142- In \\
\hline บ97 & $\mathrm{MC}+5 \% \mathrm{M}_{2} \mathrm{C}_{3}$ & 84 & INC-800 & 0.030 & 0.004 & Ho & 1750 & 18.0 & 69,000 & $x 142-\ln$ \\
\hline U98 & $\mathrm{MC}+B \mathrm{~B} / \mathrm{OM} \mathrm{M}_{3}$ & 84 & nNC-800 & 0.016 & 0.007 & Ho & seso & 21.9 & 84,000 & $x 148-10$ \\
\hline v10s & $\mathrm{MC}+5 \% / 0 \mathrm{M}_{2} \mathrm{C}_{3}$ & 64 & nNC -800 & 0.000 & 0.008 & н० & 1900 & 16.1 & 00,000 & $x 145-$ In. \\
\hline v108 & $\mathrm{MC}+5 / \mathrm{O}_{\mathrm{M}_{2} \mathrm{C}_{3}}$ & 84 & DKC-800 & 0.025 & 0.009 & He & 1828 & 10:8 & 76.000 &.$\times 148$ - id. \\
\hline U110 & $\mathrm{MC}+10 \% \mathrm{M}_{2} \mathrm{C}_{3}$ & $90^{b}$ & INC- 800 & 0.015 & 0.014 & Ho & 1980 & 21.0 & 84,000 & $x 142-12$ \\
\hline U133 & $\mathrm{MC}+10 \% \mathrm{MA}_{2} \mathrm{C}_{3}$ & $09^{b}$ & ANC-800 & 0.080 & 0.010 & H॰ & 1880 & 10.0 & 46,000 & $x 142-12$ \\
\hline v114 & $\mathrm{MC}+10 \% \mathrm{OM} \mathrm{M}_{2}$ & $99^{b}$ & INC-800 & 0.015 & 0.000 & Eט & 1075 & 2a. 1 & $18, \infty 00$ & $x+42-2$ \\
\hline
\end{tabular}

a. $\mathrm{M}=\left(\mathrm{U}_{*}, \mathrm{Pu}^{\mathrm{P}}+1 \mathrm{k}\right)$

b. Cored pollet with pominel 0.000 in. dlametor ardel hole.

\section{TABLE 463-VIII}

TASK 1030

EBR-II IRRADYTION EXPERNGENTE

\begin{tabular}{|c|c|c|c|c|c|c|c|c|c|c|}
\hline $\begin{array}{l}\text { Experiment } \\
\text { No. } \\
\end{array}$ & Fuel & $\begin{array}{c}\text { Fuel } \\
\text { Deneity } \\
\text { g.T.D. }\end{array}$ & $\begin{array}{c}\text { Cled } \\
\text { Materiol }\end{array}$ & $\begin{array}{c}\text { Clad } \\
\text { Thuekness, } \\
\text { In. }\end{array}$ & $\begin{array}{l}\text { Demotral } \\
\text { Cape io }\end{array}$ & $\begin{array}{l}\text { Tuel-to- } \\
\text { Gled } \\
\text { Bond }\end{array}$ & $\begin{array}{l}\text { Hex, fuel } \\
\text { Temp. at } \\
\text { glastup oc }\end{array}$ & 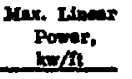 & 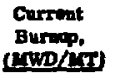 & Subuesonkty \\
\hline U120 & $\mathrm{MC}+5 \mathrm{Y} / 0 \mathrm{M}_{2} \mathrm{C}_{3}$ & 84 & 31655 & 0.022 & 0.016 & He & 1755 & 12.8 & $85, \infty 00$ & $x 000 A-t a$ \\
\hline U130 & $\mathrm{MC}+5 \% / \% \mathrm{M}_{2} \mathrm{C}_{2}$ & 75 & 31688 & 0.022 & 0.010 & He & 1500 & 28.2 & 80,000 & $x 050 A-6$ \\
\hline U131 & $M C+5 Y / O M_{2} C_{2}$ & 84 & 31688 & 0.022 & 0.010 & Ho & 1405 & 25.2 & 59,000 & $x 055 x-t a$. \\
\hline v132 & $\mathrm{MC}+5 \% \mathrm{M}_{2} \mathrm{C}_{3}$ & 84 & 31658 & 0.022 & 0.010 & H० & 1495 & 12.8 & 66,900 & 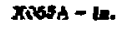 \\
\hline 0123 & $\mathrm{MC}+5 \% \mathrm{M}_{2} \mathrm{C}_{3}$ & 84 & 31088 & 0.032 & 0.010 & H० & 1495 & 12.8 & 66,000 & $x 055 A-10$ \\
\hline U134 & $M C+5 \% / O M_{1} C_{3}$ & 84 & $3108 s$ & 0.022 & 0.010 & He & 1495 & 22.6 & $5, \infty 00$ & $x 005 A-i n=$ \\
\hline U135 & $\mathrm{MC}+5 \% \mathrm{M}_{2} \mathrm{C}_{2}$ & 84 & nNC-800 & 0.022 & 0.010 & Ho & 1475 & 12,8 & 58,000 & $x 0 \sin -12$ \\
\hline U136 & $\mathrm{MC}+5 \% \mathrm{M}_{2} \mathrm{C}_{3}$ & B4 & Inc- 800 & 0.022 & 0.010 & He & 1475 & 23.3 & 87,000 & $\operatorname{xos} A-12$ \\
\hline U137, & $M C+10 \% / 0 M_{2} C_{3}$ & 89 & 31658 & 0.022 & 0.010 & Ho & 1440 & 13.4 & 07,000 & $x \cos s=12$ \\
\hline U138 ${ }^{b}$ & $\mathrm{MC}+10 \mathrm{Y} / \mathrm{OSC}_{1} \mathrm{C}_{2}$ & 80 & 31658 & 0.022 & 0.010 & IIe & 1440 & 14.8 & 18,000 & $x 055=12$ \\
\hline v139 & $\mathrm{MIC}+10 \% / 0 \mathrm{MC}_{4}$ & 90 & INC-800 & 0.022 & 0.010 & He & 1440 & 14.8 & 0,000 & xoss -6 \\
\hline U140 & $M C$ & 83 & NC-800 & 0.022 & 0,010 & Ho & 1460 & 13.9 & 58,060 & $\operatorname{xos} A-\operatorname{ta}$ \\
\hline U242 & MC & 93 & 31653 & 0.022 & 0.010 & IJe & 1460 & 14.3 & 01,000 & xoss -12 \\
\hline U:12 & MC & 93 & 31683 & 0.022 & 0.010 & H॰ & 1460 & 24.6 & 0,000 & $x+601-i n$ \\
\hline U143 & $\mathrm{MC}+10 \% 10 \mathrm{M}_{2} \mathrm{C}_{2}$ & $89^{\circ}$ & nNC-800 & 0.022 & 0.010 & He & 1395 & 19.8 & 35,000 & $x \cos s-\operatorname{sen}$ \\
\hline U144 & $M C+108 / 0 M_{2} C_{3}$ & $90^{\circ}$ & 31 Bss & 0.002 & 0.010 & Ho & 2500 & 23.1 & $B 6,000$ & xess - th. \\
\hline $\mathrm{U145}_{\mathrm{b}}$ & MC & 23 & so.ss & 0.015 & 0.000 & $\mathrm{Na}$ & 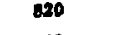 & 23.4 & 67,000 & $x \cos x$ - the \\
\hline $\begin{array}{l}\text { U146 } \\
\text { U147 }\end{array}$ & 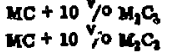 & $\begin{array}{l}99 \\
99\end{array}$ & $\begin{array}{l}\text { 3048s } \\
\text { Ne-100 }\end{array}$ & $\begin{array}{l}0.016 \\
0.016\end{array}$ & $\begin{array}{l}0.000 \\
0.000\end{array}$ & Nis & $\begin{array}{l}810 \\
810\end{array}$ & $\begin{array}{l}19.7 \\
14.8\end{array}$ & $\begin{array}{l}15)_{0}, 60 \\
60,600\end{array}$ & 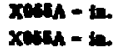 \\
\hline
\end{tabular}

a. $M-\left(U_{1}+\mu P\left(\mu_{n}-10\right)\right.$

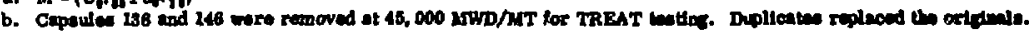

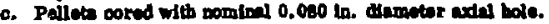

for non-destructive assay and profilometry prior to shipment to EBR-II.

A considerable effort was expended during the quarter in the routine maintenance to the fuel factlity in preparation for fuel element fabrication.

\section{TREAT Irradiation Testing}

(J. F. Kerrisk, R. E. Alcouffe, D.G. Cliftun,

K. L. Walters, J.O. Baraer)

In order to assess the bebavior of (LPu) $\mathrm{C}$ and (U, Pu)N fueled elements under fast reactor 
TABLE 463-IX

TASKOS 1930 and 1990

EBR-П IRRADIATION EXPERIMENTS

\begin{tabular}{l} 
Eupriment \\
\hline No. \\
\hline U167 \\
U189 \\
U191 \\
U192 \\
U194 \\
U195 \\
U197 \\
U198 \\
U200 \\
U206 \\
U2U8 \\
U188 \\
U190 \\
U193 \\
U196 \\
U199 \\
U201 \\
U207 \\
U209 \\
U185 \\
U186 \\
U202 \\
U208 \\
U204 \\
L205 \\
U260 \\
U261 \\
U262 \\
\end{tabular}

\begin{tabular}{|c|c|c|c|}
\hline $\begin{array}{c}\text { Fuel } \\
\text { Type }\end{array}$ & $\begin{array}{c}\text { Fuel } \\
\text { Density } \\
\text { S.T.D. }\end{array}$ & $\begin{array}{c}\begin{array}{c}\text { Clad } \\
\text { Materla1 }\end{array} \\
\end{array}$ & $\begin{array}{l}\text { Mad } \\
\text { Thlckneas, } \\
\text { In. }\end{array}$ \\
\hline$M C+5 \% / a M_{2} C_{2}$ & 84 & 32655 & 0.020 \\
\hline $\mathrm{MC}+5 \% \mathrm{M}_{2} \mathrm{C}_{3}$ & 84 & INC-800 & 0.020 \\
\hline $\mathbf{M C}$ & 23 & 30458 & 0.015 \\
\hline MIC & 83 & $3045 S$ & 0.015 \\
\hline $\mathrm{MC}+10^{\mathrm{v}} / 0 \mathrm{M}_{2} \mathrm{Cl}_{3}$ & $\theta 7$ & 30458 & 0.015 \\
\hline $\mathrm{MC}+10 \mathrm{~V} / \mathrm{O} \mathrm{M}_{2} \mathrm{CS}$ & 97 & 30485 & 0.015 \\
\hline $\mathrm{MC}+10 \mathrm{y} / 0 \mathrm{M} \mathrm{C}_{2}$ & 97 & RNC-800 & 0.015 \\
\hline $\mathrm{MC}+10^{\mathrm{V}} / \mathrm{OP}_{2} \mathrm{C}_{3}$ & $n$ & INC-800 & 0.015 \\
\hline$M C+5 \% M_{2} C_{2}$ & 84 & $304 S S$ & 0.015 \\
\hline $\mathrm{MC}+5 \mathrm{y} / 0 \mathrm{M}_{2} \mathrm{C}_{3}$ & 80 & $316 \mathrm{SS}$ & 0.020 \\
\hline $\mathrm{MC}+10 \mathrm{Y} / \mathrm{OM}_{2} \mathrm{C}_{2}$ & $97^{\mathrm{b}}$ & 31658 & 0.020 \\
\hline $\mathrm{MC}+5 \% / \mathrm{M}_{2} \mathrm{C}_{2}$ & 84 & $3165 S$ & 0.020 \\
\hline $\mathrm{AIC}+5 / \mathrm{OO} \mathrm{M}_{2} \mathrm{C}_{3}$ & 84 & INC-800 & 0.020 \\
\hline MC & 80 & 3045S & 0.015 \\
\hline $\mathrm{MC}+10^{\mathrm{Y}} \rho \mathrm{M}_{2} \mathrm{C}_{2}$ & n? & J04SS & 0.015 \\
\hline $\mathrm{MC}+10^{\mathrm{V}} / 0 \mathrm{M}_{2} \mathrm{C}_{2}$ & 97 & INC-800 & 0.015 \\
\hline $\mathrm{MC}+5 \% / 0 \mathrm{Bf}_{2} \mathrm{C}_{2}$ & 84 & $304 S s$ & 0.015 \\
\hline$M C+5 \% M_{2} C_{2}$ & 90 & 31658 & 0.020 \\
\hline $\mathrm{MC}+10 \mathrm{~V} / 0 \mathrm{BT}_{2} \mathrm{C}_{\mathrm{Z}}$ & $n^{b}$ & 31658 & 0.020 \\
\hline $\mathrm{MC}+10 \% \mathrm{M} \mathrm{M}_{2}$ & 96 & 31655 & $0.02 v$ \\
\hline $\mathrm{ACC}+10 \% / \mathrm{M}_{2} \mathrm{C}_{3}$ & 96 & 31655 & 0.020 \\
\hline $\mathrm{MC}+5 \% \mathrm{M}_{2} \mathrm{C}_{2}$ & 84 & 31658 & 0.010 \\
\hline $\mathrm{MC}+5 \% 0 \mathrm{M}_{2} \mathrm{C}_{2}$ & 84 & 31659 & 0.020 \\
\hline $\mathrm{MC}+10 \% \mathrm{OM} \mathrm{C}_{2}$ & $n^{b}$ & $31 \mathrm{ess}$ & 0.010 \\
\hline $\mathrm{MC}+10 \% \mathrm{M} \mathrm{M}_{2}$ & $n^{b}$ & $3165 s$ & 0.020 \\
\hline$M C+10 \% \mathrm{M}_{2} \mathrm{C}_{2}$ & 98 & $316^{d}$ & 0.015 \\
\hline $\mathrm{MC}+10 \% \mathrm{M} \mathrm{M}_{2} \mathrm{C}$ & 88 & $316^{\circ}$ & 0.015 \\
\hline $\mathrm{MC}+10 \mathrm{Y} / \mathrm{M} \mathrm{M}_{2} \mathrm{C}_{2}$ & 88 & TNO-800 & 0.015 \\
\hline
\end{tabular}

\begin{tabular}{l} 
Dianetral \\
Ggp.1n. \\
\hline 0.007 \\
0.007 \\
0.030 \\
0.030 \\
0.030 \\
0.030 \\
0.030 \\
0.030 \\
0.008 \\
0.008 \\
0.009 \\
0.007 \\
0.007 \\
0.030 \\
0.030 \\
0.030 \\
0.008 \\
0.008 \\
0.009 \\
0.011 \\
0.011 \\
2010 \\
2000 \\
2000 \\
2010 \\
0.015 \\
0.015 \\
0.015 \\
\end{tabular}

\begin{tabular}{|c|c|}
\hline $\begin{array}{l}\text { Fuel-te- } \\
\text { Clad } \\
\text { Bond }\end{array}$ & $\begin{array}{r}\text { Mrax. Fuel } \\
\text { Temp. at } \\
\text { Startuse. C } \\
\end{array}$ \\
\hline $\mathrm{He}$ & 1835 \\
\hline He & 1935 \\
\hline $\mathrm{Na}$ & 1148 \\
\hline $\mathrm{Na}$ & 1148 \\
\hline $\mathrm{Na}$ & 1132 \\
\hline $\mathrm{Na}$ & 1132 \\
\hline $\mathrm{Ne}$ & 1132 \\
\hline $\mathrm{Na}$ & 1132 \\
\hline He & 2042 \\
\hline He & 2084 \\
\hline Ho & 1912 \\
\hline He & 1835 \\
\hline Ho & 1935 \\
\hline No & 1148 \\
\hline $\mathrm{Na}$ & 1292 \\
\hline $\mathrm{Na}$ & 1132 \\
\hline Ho & 2042 \\
\hline He & 2088 \\
\hline He & 1905 \\
\hline He & 2195 \\
\hline He & 2195 \\
\hline He & 1270 \\
\hline Ho & 1260 \\
\hline the & 1131 \\
\hline He & 1124 \\
\hline Ho & 2590 \\
\hline He & 2690 \\
\hline В० & 2590 \\
\hline
\end{tabular}
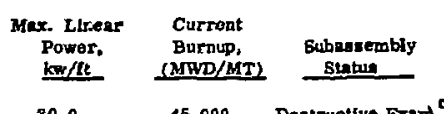

$30.045,000$ Destructive Exard $c$

$30.045,000$ Destrucuva Exam ${ }^{c}$

$31.747,000$ Destructuve Exam ${ }^{c}$

31.7 47,000 Destructive Examc

$33.1 \quad 50,000$ Destructive Exam $c$

$33.150,000$ Destructive Exam ${ }^{c}$

33.1 50,000 Destruatve Exam ${ }^{c}$

$33.4 \quad 60,000$ Destructive Exanc

30.8 46.000 Dentructive Exam ${ }^{c}$

31.5 47,000 Destructive Bram

$31.9 \quad 48,000$ Destruative Examo

$30.0 \quad 45,000 \quad 2252$

Awaillog injertlon

$30.0 \quad 45,000 \quad \times 1194$

$31.7 \quad 47,000 \quad \times 152$

$32.6 \quad 49,000 \quad \times 152$

$33.5 \quad 50,000$ Interim

$30.0 \quad 45,000$ Interim

$31.7 \quad 47,000 \quad$ Interim

$30.946,000$ Interim

$30,0<5,000 \quad \mathrm{X142}-\mathrm{In}$.

$30.0<5,000 \quad \times 142-10$.

$31.7<5,000 \quad \times 142-i n$.

$31.45,060 \quad \times 142-I D$.

$32.2<5,000 \times 142-$ in.

$31.9<5,000 \quad \times 142-10$.

34.1 Avaiting Shipment

34.1 Awalturg Sthlpmeat

34.1 Avalung Shipment

a. $M=\left(U^{*} \cdot n R^{P u_{0} \cdot t s}\right)$

b. Cored pallete with nominal $0.080 \mathrm{fn}$. diameter axill bole.

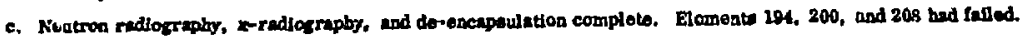

d. $20 \%$ cold-worked.

accident conditlons, transient irradiations will be conducted in the TREAT facility. Investigations will be conducted on both irradiated and unirradiated fuel pins to determine (1) the threshold power levels at which damage or fallure occurs, (2) the effect of bond and cladding defects, ard (3) the fallure propagation mechanism in multipin asgemblies.

\section{Series UL Tests}

A cooperative effort has been initiated with

Gulf United Nuclear Fuels Corporation in the area of TREAT testing. A series of four tests, designated LASL Serles UL, will determine the effect of Irradiation on the behavior of helium and sodium bonded advanced fuel elements (fabricated by Gulf United) under possible LMFBR accident conditions. Table 463-XI describes the fuel elements and test objectives. A request for approval-inprinciple has been submitted to the AEC.

\section{IASL has the responsibllity for specifying the} TREAT reactor test conditions and preparing the safety analysis required by TREAT for the Series UL tests. Neutronic calculations have been performed to obtaln an average energy calibration factor $\left(1.1 \times 10^{-1} \mathrm{MW} / \mathrm{cc}\right.$ of fuel per $M W$ r e reactor power) and its radial variation in the fuel. The edge to center power generation ratio is 


\section{TABLE 463-X}

TABK 5100

EBR-II RRADLATION EXPERTMENTS

\begin{tabular}{|c|c|c|c|c|c|c|c|c|}
\hline $\begin{array}{l}\text { Experiment } \\
\text { No } \\
\end{array}$ & Fusl & $\begin{array}{c}\text { Puel } \\
\text { Denuity. } \\
\text { \&T.D. }\end{array}$ & $\begin{array}{c}\text { Clad } \\
\text { Matorlol } \\
\end{array}$ & $\begin{array}{l}\text { Inner } \\
\text { Llner }\end{array}$ & $\begin{array}{l}\text { Dlametral } \\
\text { Gop, In. }\end{array}$ & $\begin{array}{l}\text { Asx Fuol } \\
\text { Tomp ak } \\
\text { Etaryetos }\end{array}$ & 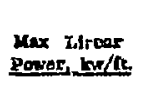 & Stentux \\
\hline t 2241 & MC & 93 & 30458 & None & 0.015 & 1175 & a6.8 & 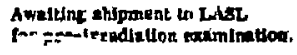 \\
\hline $\mathrm{U} 242$ & MC & 83 & 30489 & None & 0.016 & 1275 & 35.8 & $\begin{array}{l}\text { Awalung sldpment to LAgR } \\
\text { for pre-Ir raslation examinution. }\end{array}$ \\
\hline U243 & MC & 8 & 30455 & None & $0 . \cos 0$ & 1150 & 33.8 & 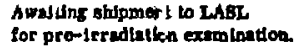 \\
\hline v244 & MC & 93 & 30489 & Nons & 0.015 & 1178 & 98.8 & $\begin{array}{l}\text { Awalting whipment to IAsL } \\
\text { for pro-Irradiation womination. }\end{array}$ \\
\hline e245 & $\mathrm{MC}$ & 93 & 30485 & Non: & 0.030 & 1160 & 53.6 & $\begin{array}{l}\text { Amalting ahipmert to LAsL } \\
\text { for pre-trendiction exominetion. }\end{array}$ \\
\hline U246 & $\mathrm{MC}$ & 28 & $316 \mathrm{SB}$ & None & 0.015 & 1180 & 36.4 & 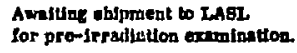 \\
\hline 0247 & MC & 03 & 31688 & None & 0.080 & 1150 & 93.8 & $\begin{array}{l}\text { Awalting phipment lo I Lorl } \\
\text { for pre-irrudiation examination }\end{array}$ \\
\hline U248 & MC & 93 & 31683 & None & 0.038 & 1240 & 36.4 & $\begin{array}{l}\text { Arraltiog oblpmont to IAsR } \\
\text { for pro-irradiation exeminntion. }\end{array}$ \\
\hline 0249 & MC & 99 & INC-800 & None & 0.015 & 1810 & 36.4 & 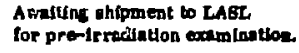 \\
\hline UP50 & ac & 13 & NC-800 & None & 0.030 & 2146 & 36,4 & 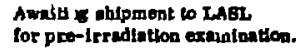 \\
\hline U251 & $\mathrm{MC}$ & 03 & 90458 & None & 0,030 & 1145 & se 4 & $\begin{array}{l}\text { Awatho chtpment to Insr. } \\
\text { tor pro-ircadiation excomination. }\end{array}$ \\
\hline U252 & MC & Q3 & $3048 s$ & Vanadlum-c lote & 0.030 & 1146 & 36.4 & $\begin{array}{l}\text { Awaltint ohtpmeat to taABL } \\
\text { tor pre-Irradiation examinztion. }\end{array}$ \\
\hline U253 & $\mathrm{MC}$ & B3 & 30458 & Iron-8lots & 0.030 & 1145 & 39.8 & 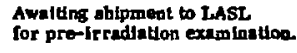 \\
\hline y254 & $\mathbf{M C}$ & Qs & 30488 & 30.458-alob & 0.030 & 1140 & 33.8 & $\begin{array}{l}\text { Awaiting abipnent to LAsL } \\
\text { for pre-irradiation examination. }\end{array}$ \\
\hline U255 & MC & 93 & 30485 & 304ss-boles & 0.090 & 1260 & 55.8 & $\begin{array}{l}\text { Awalting uhlponent to LASL } \\
\text { for pre-trradiatson }\end{array}$ \\
\hline U256 & $\mathrm{MC}+10 \% / 0 \mathrm{M}_{2} \mathrm{C}_{2}$ & 98 & 30488 & Yangadium-slob & 0.030 & 1160 & 94.0 & 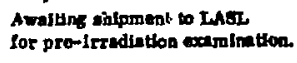 \\
\hline U257 & $\mathrm{MC}+10 \mathrm{~V} / \mathrm{O} \mathrm{M}_{2} \mathrm{C}_{2}$ & 98 & INC- -800 & Tantalum-8 $8^{\natural}$ cte & 0.000 & 123.5 & 33.5 & $\begin{array}{l}\text { Awattis shipmed to TABL } \\
\text { fer pro-lrradiation }\end{array}$ \\
\hline U258 & $\mathrm{MC}+10 \mathrm{y} / 0 \mathrm{M}_{2} \mathrm{C}_{2}$ & 28 & 30483 & so488-sloss & 0.080 & 2145 & 98.8 & $\begin{array}{l}\text { Awalting thipment to LASL } \\
\text { for pro-Irradintion examination. }\end{array}$ \\
\hline t:259 & $\mathrm{MC}+10 \% \mathrm{MH} \mathrm{C}_{2}$ & 98 & INC-800 & 30458-Eloto & 0,030 & 1150 & 34,6 & 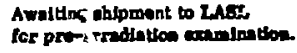 \\
\hline
\end{tabular}

a. $M=\left(\mathrm{U}_{1}, \mathrm{Pu}_{\mathrm{a}} \cdot \mathbf{1}\right)$

b. All oiements are sodlum bonded. Clad thlckess in $0.015 \mathrm{in}$. tor all elomente.

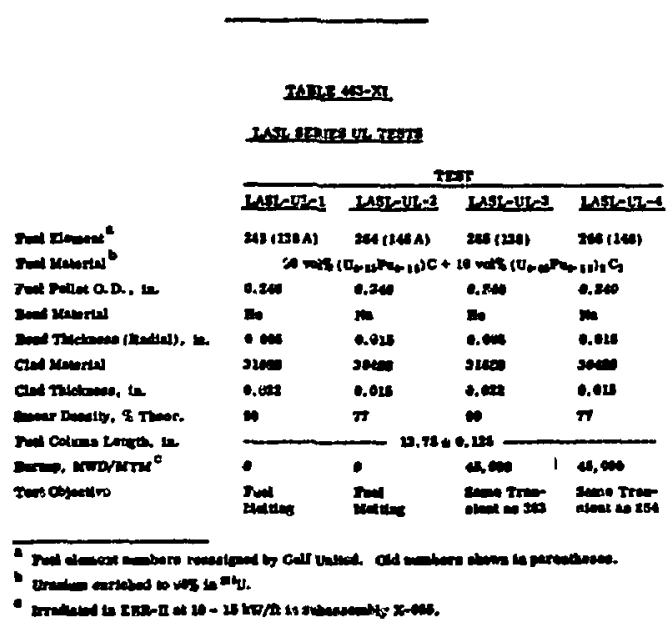

7.6/1. After a consideration of the capabilittes of TREAT It was decided to operate the reactor under computer control for these tests since the maximum power and total energy generated can be controlled more accurately in this mode. Heat transfer calculations, using the calculatec 3nergy calibration factor, indicate that a transient generating $70 \mathrm{MW}$ for $1.4 \mathrm{sec}$, with the assoctated reactor startup and shut down periods, will achleve the desired results for both $\mathrm{He}$ and $\mathrm{Na}$ bonded elements. $\mathrm{A}$, pre-trangient temperature of $260^{\circ} \mathrm{C}\left(500^{\circ} \mathrm{F}\right)$ was ohosen. The two unirradiated elements will be tested first.

('alculations for the safety analysis required for these toBts have been performed. These calculations included the nuclear effects of the experiment on the 
TREAT reactor, the nuclear effects of fuel rearrangement, the thermal and mechanical effects of the transient as planned, the thermal and mechanical effects of a larger reactivity addition than planned, and radsation hazards of the experiment. An assessment of the power generation in the end pellets of the fuel stack relative to that at the axial centerline is being made. The safety analysis is presently being written.

\section{Series 1 Tegtg}

A group of eight tests using LASL fabricated fuel elements has been designated LASL Serieg 1 tests. The tests are designed to determine if any significant safety related behavioral differences exist between sodium bonded, stainless steel elad, (U, Pu $) \mathrm{C}$ and $(\mathrm{U}, \mathrm{Pu}) \mathrm{N}$ fuels by defining fallure thresholds and the types of failure experienced by these fuels. Table 463-XII summarizes the test parameters and objectives.

Two ORNL TREAT capsules ${ }^{2}$ will be modified to incorporate a thermal neutron filter. Without the filcer, an edge to center power generation ratio of approximately $10 / 1$ would result. Calculations using rare earth metals, caimium, boron compounds, and combinations of these materials are still being performed in an attempt to

\section{TA:T:25-xiI}

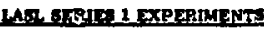

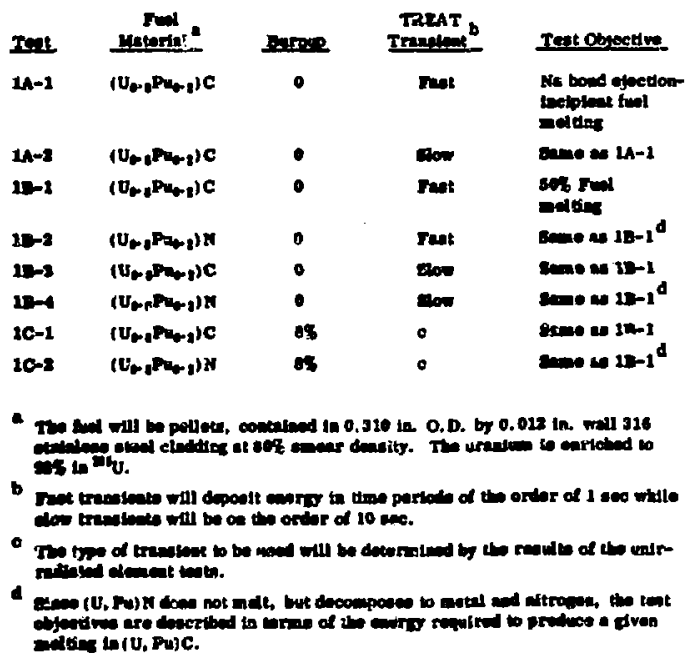

find an optimum filter.

A request for approval-in-principle is being prepared for this series.

\section{FUEL PROPERTY MEASUREMENTS}

\section{A. Differential Thermal Analysis}

(J. G. Reavis, R. Brewer)

Additional differential thermal analygis measurements have been made on irradiated $\mathrm{UO}_{2}-\mathrm{PuO}_{2}$ samples supplied by GE-Sunnyvale in a cooperative program. Samples of $\mathrm{Pt}, \mathrm{Rh}, \mathrm{Ir}, \mathrm{Al}_{2} \mathrm{O}_{3}, \mathrm{Pt}+\mathrm{C}$, and $\mathrm{MoC}_{0.2}$ have been prepared and uaed as callibration standards to reduce the uncertainty in the corrections for window $a b$ sorption which must be added to the temperatures observed by optical pyrometry.

Results of the measurements are listed in Table 463-XIII. These samples were cycled several times between $1300^{\circ}$ and selected temperatures up to and above the melting points. Good quality DTA curves were obtained for all samples up to $2100^{\circ}$ and for samples $A-1$, $A-2$, and F3B-7 through the liquidus temperature. No arrests were observed at temperatures below the "Bolldus" arrests listed in Table 463-XIII, even though it is highly probable that metallic fission product inclusions were present and molten at temperatures below $2000^{\circ} \mathrm{C}$. It would appear that thermal effects associated with these minor phases are below the limit of detection for the apparatus.

\section{TABLE 463-XIII}

\section{RESULTS OF DTA OBSERVATIONS OF UQ- $\mathrm{PUO}_{3}$ SAMPLES IN THE HOT CELL APPARATUS}

\begin{tabular}{|c|c|c|c|c|}
\hline \multirow{2}{*}{$\begin{array}{c}\text { Sample } \\
\text { No. } \\
\end{array}$} & \multirow{2}{*}{ 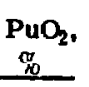 } & \multirow{2}{*}{$\begin{array}{l}\text { Burnup, } \\
\text { atomis }\end{array}$} & \multicolumn{2}{|c|}{ Arrest Temp ${ }^{\circ} \mathrm{C}$} \\
\hline & & & Solldus & Iqusdus \\
\hline$A-1$ & 25 & $\mathbf{0}$ & 2790 & 2840 \\
\hline$A-2$ & 20 & 0 & 2715 & 2780 \\
\hline F3B-7 & 25 & 4.3 & 2745 & 2785 \\
\hline E1H-29A & 25 & 7.6 & $\sim 2755$ & - \\
\hline E1H-29C & 25 & 9.0 & $\sim 2675$ & -- \\
\hline FOK-H & 20 & 5.4 & $>2710$ & $-\infty$ \\
\hline F2X & 20 & 9.7 & $\sim \mathbf{2 6 6 0}$ & \\
\hline F2G-K & 20 & 10.0 & $\sim 2625$ & - \\
\hline F2G-E & 20 & 10.6 & $\sim 2670$ & - \\
\hline
\end{tabular}


Although good quality DTA curves were obteined up to about $2100^{\circ} \mathrm{C}$ for samples having higher burnups than F3B-7, curves for these samples rapidly deterforated at temperatures above $2100^{\circ} \mathrm{C}$. Thls was caused by leakage of the seaied tungsten capsules, transport of fisslon products through the gas phase, and deposition of a film on the cooler portions of the furnace; inciuding the window through which light passed to reach the pyrometer. This produced large uncertaintes in temperature corrections and large irregularittes in the curves. Accordingly, the last six solidus temperatures listed in Table 463-XIII should be taken as estimates with a large but undetermined uncertainty.

Additional samples of each lot of oxide remain, but additional capsule development wust be done to Insure against leakage and loss of samples. Since the supply of irradiated oxide is rather limited, development work will be done with other materials to the extent that this ls possible.

\section{B. High Temperature Calorimetry of Irradiated Oxides}

(David G. Clifton, R. Brewer)

In an attempt to establish the accuracy of previously reported enthalpy values for irradiated and unIrradiated samples of $\mathrm{UO}_{2}-20 \% \mathrm{PuO}_{2}$, a serles of enthalpy measurements were made upon a sample of Standard Reference Material 720, synthetic sapphire $\left(\mathrm{Al}_{2} \mathrm{O}_{3}\right)$. These values were found to be about 1 to $3 \%$ low as reported in the last quarterly report.

Efforts have been made to locate this amall systematic error. A series of nine more electrical calibrations were made to confirm the energy equivalent of the calorimeter. Analysis of these caltbrations resulted in an energy equivalent of $2381.3 \pm .3 \%$ s.d. calorles/mv.; this is about . $2 \%$ higher than the older value.

New determinations were made of the correction factors to the pyrometer readings for the hot cell windows and the calorimeter sight ports. A small error was found in the older data reduction for the $A$ factors of the sight ports. New correction curves for these were generated. Appllcation of these slightly sltered quantities were made to the older $\mathrm{Al}_{2} \mathrm{O}_{3}$ and $\mathrm{W}$ data. Table 463-XIV lists

\section{TABLE 483-XIV}

\section{ENTHALPY OF $\mathrm{Al}_{2} \mathrm{O}_{3}$}

\begin{tabular}{|c|c|c|c|}
\hline$\underline{I}^{\circ} \mathrm{C}$ & $\begin{array}{l}\mathrm{H}_{\mathbf{T}}-\mathrm{H}_{25^{\circ} \mathrm{C}}, \\
\text { obs. }\end{array}$ & $\begin{array}{l}\text { al } / \mathrm{gm} \\
\mathrm{NgS} \\
\end{array}$ & $\begin{array}{c}\% \\
\text { Deviation }\end{array}$ \\
\hline 1298 & 349.9 & 356.2 & -1.8 \\
\hline 1398 & 381.7 & 388 & -1.6 \\
\hline 1484 & 411.7 & 414.5 & -.7 \\
\hline 1583 & 445.9 & 446 & o \\
\hline 1674 & 466.7 & 474 & -1.5 \\
\hline $1675^{a}$ & 465 & 474 & -1.9 \\
\hline $1778^{a}$ & 492.4 & 507.5 & -3.0 \\
\hline 1786 & 500.7 & 510 & -1.8 \\
\hline 1874 & 535 & 538.2 & -.6 \\
\hline $1909^{q}$ & 542.3 & 550 & -1.4 \\
\hline
\end{tabular}

a Data taken with new pyrometer.

these recalculated values plus three additional $\mathrm{Al}_{2} \mathrm{O}_{3}$ enthalpy determinations. The additional data were taken with a different pyrometer which has recently been callbrated by Sandis Laboratorles, with a newly callbrated calorimeter sight port, and with the latest confirmed hot cell window correctione. Included in the Table are the NBS values and percentage ciavlation of the observed values. From these data, it is seen that the eystemntic error now appears to be from 0 to $2 \%$ low, excepting the one very recent foint taken at $1778^{\circ} \mathrm{C}$.

Investigation of the possibilty that a temperature gradient in the tungeten capsule may exist due to heat leaks into the support and drop mechantem was explored. A 1/2 in. O.D. $\times 13 / 4$ in, long tungeton alug was put into a typical tungaten capsule ind drops wore made at $1727^{\circ} \mathrm{C}$ and $1781^{\circ} \mathrm{C}$. The total mesaured enerwy was reduced by the amount ascribed to an empty tungeten capaule of the proper weight (as determined by the previouly acquired "apparent" tungeten enthalps" curves) and the remalaing onerwy was asaigned to the tungaten slus. Aasuming that radiative losees are the anme for the losied and impty copsules and furthermore sosumine that if a temperature gradlent exints in the syetem it in the same for both the fllled and empty capeulea, the resulting entialpy valus 
for the tungsten slug should be a value corresponding to some average temperature about midiway in the temperature gradient. Comparison of the enthalpy value for tungsten obtained in this way with the value given in the JANAF tables gives a corresponding temperature. This temperature could be assumed to be the average temperature of the sampling. Comparison of this temperature with the observed temperature would provide some measure of the temperature gradient. Such comparisons indicated our observed temperatures to be $54^{\circ}$ and $70^{\circ} \mathrm{C}$ high, respectively. Attempts to correct the $\mathrm{Al}_{2} \mathrm{O}_{3}$ data by increments of this size caused all of the $\mathrm{Al}_{2} \mathrm{O}_{3}$ data to then be about 2 to $4 \%$ higher than the NBS data.

Based on reasoning similar to the above, another series of three observations were taken at 1640, 1739, and $1810^{\circ} \mathrm{C}$ for a second sample of $\mathrm{Al}_{2} \mathrm{O}_{3}$ that was only about one half the weight of the previous samples. In these cases, one would expect the average temperature of the smaller charge to be closer to the observed temperature; hence, the determined enthalpy values should be closer to the NBS values. Such was not the case; in fact they were the same or slightly worse than the previous $\mathrm{Al}_{2} \mathrm{O}_{3}$ data. This possibly could be attributed to the fact that now the energy effect due to the $\mathrm{Al}_{2} \mathrm{O}_{3}$ Is a smaller portion of the total measured energy and the precision of the measurements suffer.

The results of the above experiments indicate that the 0 - $2 \%$ systematic error in the $\mathrm{Al}_{2} \mathrm{O}_{3}$ enthalpy measure ments is still not resolved.

It is planned to continue extending the enthalpy measurements on the Irradiated and unirradiated $\mathrm{UO}_{2}-$ $20 \% \mathrm{PuO}_{2}$ and concurrently to take more data on the turgsten slug and $\mathrm{Al}_{2} \mathrm{O}_{3}$ samples. The comparative feature of the Irradlated and unirradiated samples of $\mathrm{UO}_{2}-20 \%$ $\mathrm{PuO}_{2}$ should atill be valid and with further information for the tungsten and $\mathrm{Al}_{2} \mathrm{O}_{3}$ samples the present accuracy difficulties should be resolved.

\section{c. $\mathrm{UO}_{2}$ Heat Content}

\section{(J. F. Kerrisk and D. G. Clifton)}

The heat content of $\mathrm{UO}_{2}$ has been measured by a number of different investigators in the temperature range from 483 to $3107^{\circ} \mathrm{K} .{ }^{3-8} A$ total of 105 date pointa are available in this temperature range. Each investigator normally fits his data to some functional form of temperature over the range of the data, and reports this function as a representation of the heat content. Common functions include polynomials in temperature and inverse temperature. $^{3,7}$ For use, the functions representing heat content as a function of temperature are often differentiated to obtain the specific heat. A comparison of the specific heat curves of diffelent investigators in a temperature range where they overlap shows significant variations in the specific heat and its curvature. 7,9 This magnification of error in the slope (specific heat) of a fitted function (heat content) is well known. 10

The object of this investigatton is to fit ail available heat content data for $\mathrm{UO}_{2}$ to one function over the temperature range from 298 to $3107^{\circ} \mathrm{K}$. The function must be smooth enough to provide a reasonable representation of the specific heat when differentiated. Since the heat content is normally reported as $[H(T)-H(298)]$, the Eunction should be constrained to be zero at $298^{\circ} \mathrm{K}$. The specific heat of $\mathrm{UO}_{2}$ has been measured below $300^{\circ} \mathrm{K}$ by several investigators. 11,12 To make use of this information, a second constraint can be placed on the selected heac content function, 1. e., fixing its slope (speciflc heat) at $298^{\circ} \mathrm{K}$. Initially the specific heat of $\mathrm{UO}_{2}$ at $298^{\circ} \mathrm{K}$ was fixed at $15.2 \mathrm{cal} / \mathrm{mole}^{\circ} \mathrm{K}$.

Two types of functions are being Investlgated initially, polynomials and spline functions. ${ }^{13}$ Polynomials have the advantage of simplicity but derivatives of fitted polynomials tend to osclllate around the true curve. Spline functions are smoother functions but more cumbersome to evaluate. ${ }^{14}$ The spline fjtting program used requires that the internal knots be epecified. Thus an optdmum spline function fit sith a given number of internal knots cannot be obtained in a single computer run. Functions with 3 to 5 free parameters are being investigated.

\section{PUBLICATIONS}

1. "Transformation Temperaturea of Irradiated $\mathrm{UO}_{2}-\mathrm{PuO}_{2}$ Fast Breeder Fuels," J.G. Reavis and J.L. Green, Trans. Am. Nuclear Soc. 14, No. 2 (1971) pp 593 - 4. 
2. "A Differentlal Thermal Analysis for Observation of Irradiated Pu-Containing Reactor Fuels," J.G. Reavis, G.R. Brewer, D.B. Ccurt and J.W. Schulte, Proceedings of the 19 th Conference on Remote Systems Technology (1971) pp 112-117.

3. M. Tokar and J. L. Green, "Hot Hardness Testing of Uranium-Plutonium Ceramlcs", presented at the International Symposium on The Science of Hardness Testing and Its Research Applications, Oct. 18 - 21, 1971 Detroit, Michigan.

\section{REFERENCES}

1. "Quarterly Status Report on the Advanced Plutonium Fuels Program, July 1 to September 30, 1971," Los Alamos Scientific Laboratory Report LA-4841 MS (1971).

2. C. M. Cox and R. E. Adams, "Safety Analysis and Test Specifications for Translent Tests of Sol-Gel (U, $\mathrm{Pu}$ ) $\mathrm{O}_{2}$ Fuel Pins (ORNL Series I), " Oak Ridge National Laboratory Report ORNL-TM-3574 (1971).

3. G. E. Moore and K. K. Kelley, J. Am. Chem. Scc. 69, 2105 ( 1947 ).

4. J.B. Conway and R.A. Hein, J. Nucl. Materials $\underline{15}, 149$ (1965).

5. R. A. Hein, L.H. Sjodahl, and R. Szwarc, J. Nucl. Materials 25, 99 (1968).

6. L. Leibowitz, L.W. Mishler and M. G. Chasanov, J. Nucl. Materials 29, 356 (1969).

7. D.R. Frederickson and M.G. Chasanov, J. Chem. Thermodynamics 2, 623 (1970).

8. A. E. Ogard and J.A. Leary, "High Temperature Heat Content of $\mathrm{UO}_{2}, \mathrm{~L}$ bby-Cockcroft Plutonium Informational Exchange, Argonne National Laboratory, October 19-20, 1970 .

9. A.E. Ogard and J.A. Leary, "Thermodynamics of Nuclear Materials, 1967," IAEA, Vienna, 651 (1968).

10. H.C. Joksch, SLAM Rev. 8, 47 (1966).

11. W. M. Jonea, J. Gordon, and E. A. Long, J. Chem. Phys. 20, 695 (1952).

12. J.J. Huntzicker and E. F. Weatrum, Jr., J. Chem. Thermodynamice 3,61 ; 1971 ).
13. T.N. Greville (ed.), "Theory and ApplicaHons of Spline Functiong", Academlc Press, New York, 1969.

14. J.G. Hayes (ed.), "Numerical Approximation to Functions and Data", Athlone Press, London, 1970,11 . 12-15. 
PROJECT 472

\title{
ANALYTICAL STANDARDS FOR FAST BREEDER REACTOR OXIEE FUEL
}

\author{
Person in Charge: $\quad$ R. D. Baker \\ Principal Investigator: C. F. Metz
}

\section{INTRODUCTION}

Necessary to the development of the high quality fuels and control rods required by the LMFBR program are highly reliable analytical methods for the chemical characterization of the source materials and the pellet product and for the examination of irradiated specimens.

The immediate objectives of this project are (1) the evaluation of existing methods for the chemical characterization of boron carbide to be used as the absorber for FFTF control rods; (2) the development of improved methods, as required, for mixed axide fuels, advanced fuels, and boron carbide; (3) the preparation of extremely well characterized callbration materials for the various chemical specification analyses performed at the fuel producers' and buyer's facilities for the above materials; (4) the preparation of continuously updated compilations of analytical methods for the above materials; (5) the development of quality asgurance programe for chemical specification sampling and analysis of the above materials; (6) the preparation of quality control samples used for the continuous serveillance of analytical chemistry laboratory operations during periods of fuel pin and contrcl rod production; (T) serve as a "neutral" referee laboratory, as may be required, to analyze samples in dispute between a producer and buyer; and (8) measure the tritium content of irradiated fuel pins processed at LASL (under the 07401 Program) to establinh the degree of diffusion of this gas through the fuel cladding. These objectives will be extended, as required, to the LMFBR demongtration plants.

Other objectives, concerned with irradiated fuel casamination, are (1) development of fuel burnup measurement methods based on conventional and spark source mass spectrometric determinations of actinide and fission product lsotopes; (2) development of fagter fuel burnup measurement methods based on chemical analysis techniques for use for larger routine sample loads; (3) correlation of nondestructive gamma ray scans of whole fuel pins with destructive burnup measurements to assess the reliability of gamma scanning for measurement of burnup; (4) correlation of burnup measurements with other measurement techniques including electron microprobe and metallographic examinations to assess irradiation behavior of LMFBR fuels; (5) development of analytical methods for impurity and fission gases in pre- and postirradiated fuels to provide for studies of fuel gas retention properties and cladding stabllity; and (6) application of the ion microprobe analysis technique to study migration mechanisms in irradiate fueld.

\section{ANALYTICAL CHEMISTRY PROGRAM FOR BORON CARBIE}

The proposed neutron absorber material for LMFBR/FFTF control rods is boron carbide pellets. A coordinaied program with HEDL is under way to establioh the status of analytical methods for the chemical charecterization of boron carbide and to develop improved methods as necessary.

A. Status of Analytical Methods

(J. E. Rein, C. F. Metz)

In the preceding quarterly report ${ }^{(1)}$, the status of analytical methods for seven chemical specifications of boron carbide pellets was reported besed on a round robin sample exchange program. Impruvements in the methods for the determinations of coluble boron, coluble carban, chloride and fluoride, and metal impurities were deemed desirable on a high priority basis for use in the FFTF 
vendor qualifination program. Improvements made in this laboratory of these methads are reported in subsequent secticas. The other two laboratories, HEDL and ORNL, participating in the round robin program also improved methods. An evaluation of the improved methods is under way by means of a second round robin program. The round robin samples include a batch of pellets supplied by HEDL and special powder blends prepared at LASL.

B. Studies and Improvements of Analytical Methods

1. Emisgion Spectrographic Determination of Metal Impuritles

(O. R. Simi, R. T. Phelps)

Boron carbide pellets and powder are analyzed for metallic impurities by a tentative emission spectrographic method described in HEDL TME-71-54, Method No. 20.4. In this method, a $20 \mathrm{mg}$ portion of a mixture containing $10 \% \mathrm{~B}_{4} \mathrm{C}$ sample, $22.5 \% \mathrm{GeO}_{2}$ and $67.5 \%$ graphite powder is burned to completion in a $17 \mathrm{amp}$ (short circuit measurement) d.c. arc. The spectra are recorded on S.A. -1 spectrographic plates. Results are obtained by visual comparison of analytical lines in the sample spectra with spectra of calibration materials on a previously prepared calibration (referience) plate.

Several modifications of this method have been reported previously. (1) These are: (1) use of one set of calibration materials to contain all the required impurity elements in coucentrations graded, generally, from 0.1 to $4 \mathrm{X}$ the specification limits, (2) exposure of the calibration materials on the same spectrographis plate as the samples, (3) use of a grating spectrograpt with a reciprocal linear dispersion of $5 \AA / m m,(4)$ use of a centerpost electrode, and (5) addition of $\mathrm{B}_{4} \mathrm{C}$ matrix to the calibration materials.

The major problem remaining in this method is the lack of sufficiently pure $\mathrm{B}_{4} \mathrm{C}$ for matrix material in the calibration materials. Attempts to purify the best avallable $\mathrm{B}_{4} \mathrm{C}$ by various acid leachings at atmospheric pressure were not successful. Use of a teflon-lined bomb, however, with a mixture of 3 parts $\mathrm{HF}$ and 1 part $\mathrm{HNC}_{3}$ held at $150^{\circ} \mathrm{C}$ for $16 \mathrm{~h}$ reduced the impurity content of the $\mathrm{B}_{4} \mathrm{C}$ to a level tentatively acceptable for the calibration materials. The analyses of the starting material
$\mathrm{B}_{4} \mathrm{C}$ and the purified $\mathrm{B}_{4} \mathrm{C}$ are given in Table 472-I. Although this leaching process improved the material, it is not considered pure enough for extensive usage as matrix material.

TABLE 472-1 Purification of $\mathrm{B}_{4} \mathrm{C}$ in a Teflon-lined Bomb

\begin{tabular}{|c|c|c|c|c|}
\hline Element & \multicolumn{4}{|c|}{$\begin{array}{l}\text { Conceatration of impurity element, } \mu \mathrm{g} / \mathrm{g} \\
\text { Staring Material } \mathrm{B}_{4} \mathrm{C}\end{array}$} \\
\hline Al & & 150 & & 50 \\
\hline Bd & $<$ & 25 & $<$ & 25 \\
\hline $\mathrm{Ca}$ & & 80 & & 50 \\
\hline Co & $<$ & 50 & $<$ & 50 \\
\hline $\mathrm{Cr}$ & $<$ & 100 & $<$ & 100 \\
\hline $\mathrm{Cu}$ & & 10 & $<$ & 10 \\
\hline $\mathbf{F e}$ & & 700 & $<$ & 200 \\
\hline $\mathbf{M g}$ & & 20 & $<$ & 20 \\
\hline $\mathbf{M n}$ & $<$ & 20 & $<$ & 20 \\
\hline NI & $<$ & 40 & $<$ & 40 \\
\hline Si & & 800 & & 150 \\
\hline $\mathbf{T} \mathbf{i}$ & $<$ & 50 & $<$ & 50 \\
\hline $\mathbf{V}$ & $<$ & 40 & $<$ & 10 \\
\hline $\mathbf{Z r}$ & $<$ & 290 & & 60 \\
\hline
\end{tabular}

The list of analytical lines for visual comparison and photometric evaluation has been revised. The current lists are presented in Fables II and III. To fncrease the concentration range covered by several of the lines, a twostep exposure, with $100 \%$ and $15 \%$ trangmission stepe, is emploged.

These modifications were incorporated in a method "Determination of Metal Impurities in Boron Carbide by Emission Spectroscopy" which was selt to HEDL and ORNL for evaluation. Accompanying this method were a get of calibration materials made with the purified $B_{4} C_{\text {. }}$

\begin{tabular}{|c|c|c|c|c|c|}
\hline \multicolumn{6}{|c|}{ TADLE Are-D } \\
\hline Elespent & Anelytical Lne, & Conce Bante, writs & 보르료 & Anelyeteal 1 1 & 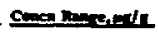 \\
\hline $\mathbf{M}$ & $\begin{array}{l}3000.2 \\
3092.7\end{array}$ & $\begin{array}{l}90 \text { to } 1000 \\
50 \text { to } 1000\end{array}$ & Ws & 275.3 & 20 to 390 \\
\hline $\mathbf{B}$ & 3057.7 & 25 to 1000 & un & 2576,1 & 20 to 2000 \\
\hline$C_{n}$ & $\begin{array}{l}3800.5 \\
3170.3\end{array}$ & $\begin{array}{l}300 \text { to } 1000 \\
50 \text { to } 450 \\
450 \text { to } 4000\end{array}$ & Mi & $\begin{array}{l}1001.1 \\
3011.0 \\
300.3\end{array}$ & 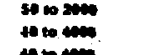 \\
\hline$c_{0}$ & $\begin{array}{l}3495.5 \\
3040.0\end{array}$ & $\begin{array}{r}50 \text { to } 2000 \\
200 \text { to } 2000\end{array}$ & 31 & $\begin{array}{l}3002.3 \\
3461.0 \\
2511.3\end{array}$ & 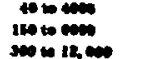 \\
\hline $\mathrm{Cr}_{\mathrm{r}}$ & $\begin{array}{l}2435,6 \\
3043,2\end{array}$ & $\begin{array}{l}200 \text { to } 4000 \\
200 \text { to } 4000\end{array}$ & $\mathbf{T i}$ & $\begin{array}{l}304.0 \\
3231.5\end{array}$ & sen \\
\hline Cu & $\begin{array}{l}3274.0 \\
3217.5\end{array}$ & $\begin{array}{l}20 \text { to } 2000 \\
20 \text { to } 2000\end{array}$ & v & $\begin{array}{l}3110.7 \\
3110.6\end{array}$ & to is \\
\hline$r_{6}$ & $\begin{array}{l}23 \% .4 \\
214.5\end{array}$ & $\begin{array}{r}200 \text { to } 20,000 \\
2000 \text { to } 20,000\end{array}$ & $\mathbf{z r}$ & $\begin{array}{l}3913.0 \\
3650.2\end{array}$ & $\begin{array}{l}c 0 \text { to tam } \\
100 \text { to tape }\end{array}$ \\
\hline
\end{tabular}


There 472-m

Anelyticel Line For Amlyate of Boroa Carbide

By Mtlerophotometry

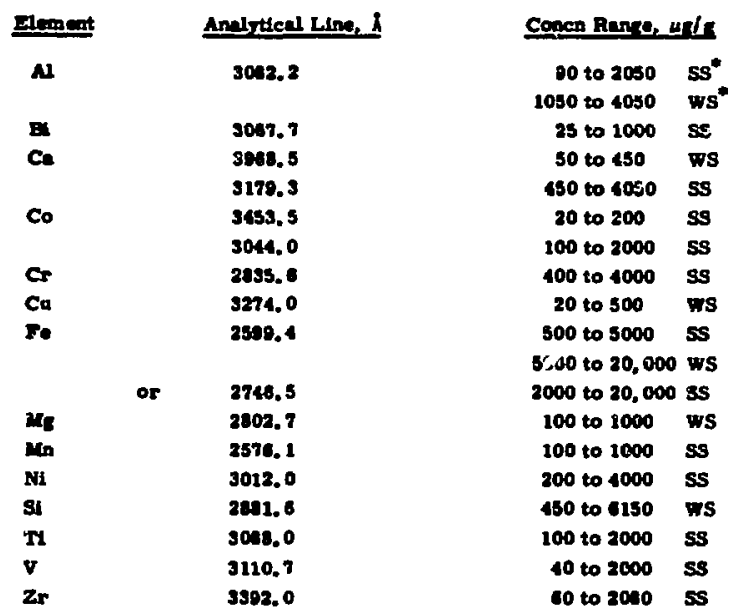

- ss mean strons (derb) step of the epretrum, FS means weak (Liph) step. Note 1. An extrapolation of approximately 16 times the intenaity of the

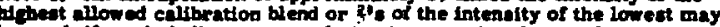
be used; if reed, indicate extrapolition in reportins the result.

Note a. The Cs 3179 I Lne has a weals interfering line which is lanored

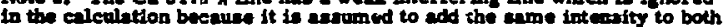
in thile and enllibrition bled.

a box of center-poet electrodes, and a supply of $\mathrm{GeO}_{2}-$ graphite powder bunfer mixture.

A longer term development effort will be made to find an alternate method for $\mathrm{B}_{4} \mathrm{C}$ analysis. Fusion of $\mathrm{B}_{4} \mathrm{C}$ in $\mathrm{Na}_{2} \mathrm{CO}_{3}$, with subsequent conversion of the melt to $\mathrm{NaCl}$, appears to be a promising technique.

2. Determination of Soluble Boron

(R. D. Gardner, W. H. Ashley)

Work on a flame emission for measuring the soluble boron in boron carbide was discussed in the Quarterly Report for the period ending September 30, 1971 (LA4841-MS). Thts work heo been continued and a complete procedure has been written. A copy of the procedure has also been submitted to HEDI for comment. The samples are digested under reflux with 0 . IN hydrochloric acid and with 1.6N nitric acid as described in HEDL-TME-71-54,
Method 20.2, but instead of trtrating the dissolved boron a small portion of the solution is purified by passage through a cation exchange column and the boron in the effluent is measured by flame emisaion at $5476 \dot{A}$ in a very lean nitrous oxide-acetylene flame.

Pellet samples were used for comparing the results by flame emission measurement with those by titration. Method 20.2, as revised by HEDL to include cation exchange purification of the extract solution before titration was used to make this comparison. Flame emission measurements of solutions of hydrochloric acid-soluble boron gave an average for 6 determinations of $0.46 \%$ with an absolute standard deviation of $0.04 \%$. Titration of the ramainders of the solutions gave in average value of $0.49 \%$ with an absolute standard deviation of $0.04 \%$. For nitrlc acid soluble boron, flame emission measurements of 6 extracts gave an average value of $0.79 \%$ with an absolute standard deviation of $0.07 \%$, and titration of the game extracts gave an average boron value of $0.73 \%$ with an absolute standard deviation of $0.07 \%$.

The use of only a portion of the extraction solution to measure the boron proved advantageous in a study of the relationship between the amount of boron dissolved and the time of digestion. Individual samples were placed in the refluxing apparatus and the progress of the digestion was followed by withdrawing 5 milliliters of the solution at regular intervals for boron messurement. The hydrochloric acid-8oluble boron seemed to be relatively constant over an acid treatment period of 1 to 5 houra, regardless of the particle size of the sample. The nitric acid solubleboron was dependent, in some aamples, on both particle size and time of digestion. A sample of powdered material showed $0.51 \%$ of nitric acid-soluble borce after $2 \mathrm{~h}$, $1.91 \%$ after $18 \mathrm{~h}$, and $2,62 \%$ after $26 \mathrm{~h}$. Some cryatalline material was crushed and sieved into two fractions 
(100-200 mesh and -200 mesh). The hydrochloric acidsoluble material was removed before applying the nitric acid digestion. Under these conditions the coarser fraction showed no significant increase of dissolved boron after the first hour of acid treatment analyzing $0.31 \%$ after $1 \mathrm{~h}$ and $0.34 \%$ after $7 \mathrm{~h}$ of treatment. The finer portion yielded $0.55 \%$ after $1 \mathrm{~h}$ and increased regularly to $0.79 \%$ after $7 \mathrm{~h}$ of treatment.

A sample of pelletized material was ground and sieved in the same way. The hydrochlortc actd-Boluble part was not separated in advance. The nitric acid-soluble boron was constant in both size fractions, yielding $0.8 \%$ at the end of 2,3 , and $4 \mathrm{~h}$ respectively. Another portion of the same meterial was followed for $112 \mathrm{~h}$ and increased only to $1.1 \%$ during that time.

Nothing was found in this study to suggest any bettor way to dissolve the free boron than the digestion conditions proposed in HEDL-TME-71-54. For its measurement, however, flame emission technique seems to have advantages.

3. Determination of Soluble Carbon

(A. L. Henlcksman, R, D. Gardner,

W. H. Ashley)

The cause of high bias in the soluble-carbon values has been found and corrected. The fault lay in not drying the effluent stream of nitrogen sufficiently before measurIng the carbon dioxide. The manometric apparatus described in the HEDL tentative procedure (Method 20.1) has been constructed and its performance verifled by the collection and mousurement of known amounto of carbon dioxide derived from a sodium carbonate standard solution. Using this apparatus, further analyses have been made on a mixture of pellets. Eight soluble-carbon values on this material gave an average value of $0.50 \%$ with a relative standard devlation of 12\%. The reported HEDL average value was $0.69 \%$ and the relative standard deviation was 9\%. The two clusters of values actually touch. This agreement is probsbly sufficient for any present purpose.

On another serles of pellet samples method $\mathbf{2 0 . 2}$ from HEDL-TME-71-54 was used except that a HEDL modification involved a temperature change from $100^{\circ} \mathrm{C}$ to $100-110^{\circ} \mathrm{C}$ for the acid digention step. The performance of the apparatus was checked during the analysis of this series by measurement of carbon dioxide from a sodium carbonate standard solution. During the acid-digestion period a thermometer was immersed in the oxidizing reagent and kept at a reading of $105 \pm 2^{\circ} \mathrm{C}$. A total of 7 determinations were made with an average of $1.15 \%$ and a relative standard deviation of $7 \%$.

It was found that the measured soluble carbon is not very sensitive to the duration of the acid-digestion treatment. The analyses of pellets described above gave an average for 8 determinations of $0.50 \%$ after a digestion time of $1 \mathrm{~h}$. When 4 additional portions of this material were treated for $1.5 \mathrm{~h}$, the soluble carbon was found to increase only slightly to $0.52 \%$. On the other hand, increasing the digestion tomperature from 100 to $110^{\circ} \mathrm{C}$ resulted in an increase from 0.50 to $0.67 \%$ for the soluble carbon value, in 12 determinations. When the scatter of individual measurements is considered, this efiect is not gceat. Further increase to $120^{\circ} \mathrm{C}$ for 3 determinations confirmed the trend, giving an average measured palue of $1.17 \%$.

\section{Further Dissolution Studies With Sulfuric Acid-} Dichromate Reagent

Work has been done also on the dissolution rateg of boron and carbon in the sulfuric-sodium dichromate reugent. A spectrophotometric method using methylene blue $^{(2)}$ was used for measuring the dissolved boron. The method depends upon the formation of $\mathrm{BF}_{4}^{-}$by treatment with dilute HF solution, reaction of the complex ion with methylene blue, and extraction of the colored product with dichloroethylene. The applicability of the method to the analysis of the digestion solution was verlfied with known amounts of boric acid added to the rengent wolution. The sensitivity of the method is great enough 10 that only 100 microliters of the digesting solution 18 required for an analysis, and the result is accurate to $a$ fow percent. In the operation of the soluble carbon apparative the nitrogen sweep gas is interrupted and the appentus retain aw carbon diaxide evolved during the meanuremant time. it is possible to analyze a single sample by meanuring nuocessive increments of carbon dioxide at anj obonen time interval, and the 100-micraliter anmple for boron 
determination may be taken at the same time.

Ground samples were analyzed in $1 \mathrm{~h}$ intervals, using a 100-milligram sample and a digestion temperature of $100^{\circ} \mathrm{C}$. In these materials the rates of dissolution of boron and carbon were greatest during îlie first hour diminishing to a constant rate in 4 or $5 \mathrm{~h}$. Succeeding intervals, up to $10 \mathrm{~h}$ in some cases, showed no further change. Figure 472-I is a typical plot showing the treed of the values. The atom ratios of boron and carbon that dissolved after $5 \mathrm{~h}$ corresponded to the formula $\mathrm{B}_{4} \mathrm{C}$, and there was no apparent change in the rate of dissolution per hour that might be attributed to depletion of the reagent. The soluble-carbon was calculated from the measurements of carbon dioxide made after an hour of leaching was found to be 0.93 and 1.00\% in two analyses that were followed by digestion treatments of 8 and $6 \mathrm{~h}$. The value was confirmed by timee more determinations which were terminated at $1 \mathrm{~h}$ with soluble-carbon values of 0.93 , 1.00 , and $0.87 \%$.

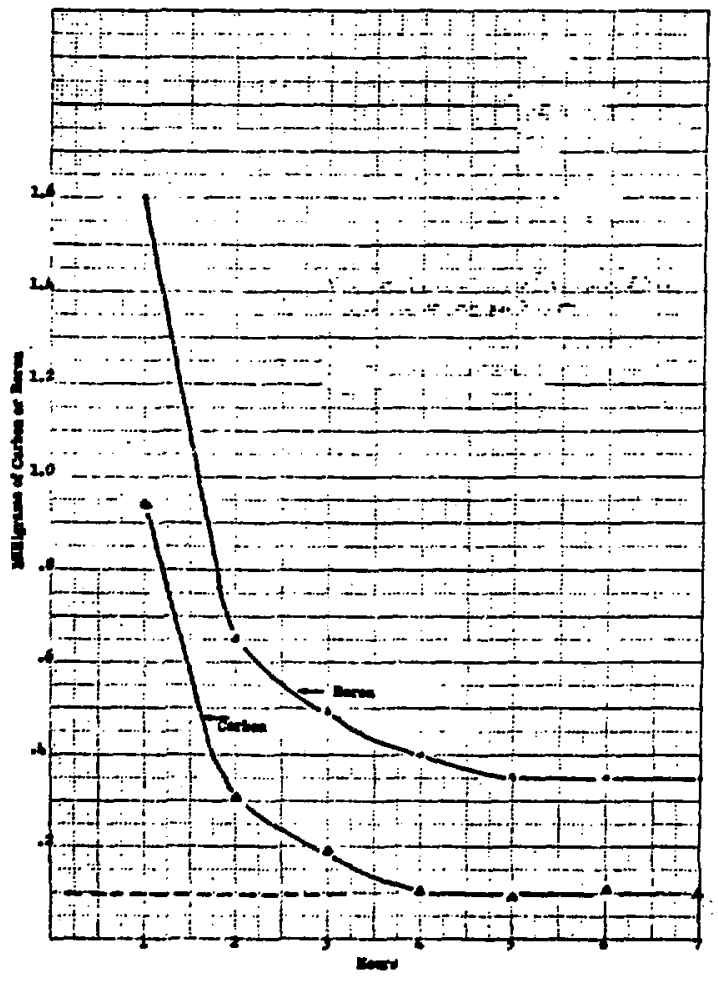

Fig. 472-I Rate of Dissolution of Powdered Samples Expressed ae Mg Per Hour
The fine material, which passed a 200-mesh sieve, was also analyzed. The first experiment was terminated with loss of the sample after obtaining the measurement of soluble carbon following $1 \mathrm{~h}$ of leaching -- 1.27\%. In the second experiment the leaching was allowed to continue for $6 \mathrm{~h}$ and gave $a$ value for the soluble carbon of 1.17\%. The soluble carben in this material was therefore approximately $20 \%$ greater than that in the 100-200 mesh fraction when both were measured according to the HEDL procedure. Other observations on the analysis of the finely ground material were understandable on the basis of particle size. The absolute amounts of both boron and carbon dissolved in $1 \mathrm{~h}$ were 2 or 3 times as great, but there was little change in the shape of the plot oi weight rate of dissolution versus time.

Inspection of Fig. 472-I suggests that the soluble carbon measured after $1 \mathrm{~h}$ should be corrected by aubtracting an estimate of the boron carbide dissolved during that hour. The assumption that the boron carbide dissolution is constant from the start (the dotted line in Fig. 472-I is a tempting one, and this approach has been used by Kitahara ${ }^{(3)}$. It has also been stated ${ }^{(4)}$ that the rate of attack on $\mathrm{B}_{4} \mathrm{C}$ is lower during the early part of the digestion when most of the free carbon is dissolved. Evidence on this point was sought as follows: Digestion with 1.6M nitric acid removed boric actd, soluble boron, and possibly some free carbon as welk, producing the nearest thing to pure boron carbide available at present. Some nitric acid digested material from a previously treated material from which the -200 mesh fraction had not been remuved, was washed, dried, and analyzed. In these experiments, the carbon and boron were messured at 10min intervals during the first hour and hourly thereafter. The absolute amounts of boron and carbon to be measured were small, so the sample size was inoreased to 150 milligrams and the boron determinations were made on duplicate 100-microliter portions. The plot of boron and carbon values looks very much like Fig. 472-I, except that the rapid initial dissolution rate declined very sharply to a constant rate by the end of $1 \mathrm{~h}$. The ratio of the welghts of boron and carbon was quite constant during the first hour at 2,7 ( $B_{4} C$ would be 3,6$)$, Indtonting that 
the soluble carbon was not removed by the nitric acid pretreatment but was dissolved during the first hour of oxidation. There appears to be no indication of slower initial dissolution of $\mathrm{B}_{4} \mathrm{C}$.

A correction to the measured soluble carbon value, based on the constant rate of dissolution of $\mathrm{B}_{4} \mathrm{C}$ observed after 3 to $5 \mathrm{~h}$ digestion, does not appear Justified. The experiments with nitric acid-extracted material indicate that boron carbide dissolution is more rapid in the first hour, so the simple extrapolation shown by the dotted line in Fig. 472-I would not be correct, and the time required to reach the horizontal part of the curve would be largely wasted. As the HEDL recommended procedire stands, it ignores two biases of opposite sign. There is a positive bias introduced by the solubility of $\mathrm{B}_{4} \mathrm{C}$ and a negative bias from Ignoring the carbon diaxide produced after the first hour. Since a legitimate correction for the solubility of $\mathrm{B}_{4} \mathrm{C}$ is lacking, it is probably bost to let both biases stand untll additlonal work proves otherwise.

III. ANALYTICAL CHEMISTRY PROGRAM FOR LMFBR/FFTF FUEL

A. Calibration Materials and Quality Contro] Samples

(J. E. Rein, R. K. Zeigler, R, T. Phelps, C. F. Metz)

The powder blends of metal and nommetal impurities in matrices of uranium-plutonium mixed axide, uranium oxide, and plutonium oxide, prepared for use as calibration materials and quality control samples have been sext to HEDL for the fuel pin vendor gxalffication program. The transmittal letter to the HEDL Quality Assurance Section included recommended limits for the analytical results on the quality control samples.

\section{B. Determination of $O / M$ Atom Ratios (J. W. Dahlby)}

The determination of $\mathrm{O} / \mathrm{M}$ atom ratios in mixed axide fuels was investigated further by comparing results obtained at LASL and HEDL using two thermogravimetric methods on one lot of alntered $(\mathrm{U}, \mathrm{Pv}) \mathrm{O}_{2}$ pellets. In the method used at LASL, the pellets were dried in helium, at $120^{\circ} \mathrm{C}$, welghed, oxidized in air at $1000^{\circ} \mathrm{C}$, and then reduced at $1000^{\circ} \mathrm{C}$ in helium containing 6 at. $\%$ hydrogen. At HEDL, the weighed pellets were heated to $800^{\circ} \mathrm{C}$ in argon containing 8 at. $\%$ hydrogen and water vapor at a partial pressure of $4 \mathrm{~mm}$. In each case, the change in weight was used in calculating the $\mathrm{O} / \mathrm{M}$ atom ratto. To eliminate possible bias caused by heterogenelty or different storage or handling conditions, personnel at HEDL ramdomly chose forty pellets from a batch which had been previously analyzed and determined to be homogeneous in O/M ratio. Twenty of the pellets were shipped to LASL while the remaining 20 pellets were stored in an identical shipping container at HEDL. Each of the shipping containers was opened on the same day and the measurements of $\mathrm{O} / \mathrm{M}$ ratios were started immeditely by each laboratory.

The average of $1.964 \pm 0.002$ obtained at LASL for the $\mathrm{O} / \mathrm{M}$ ratio on elght samples each containing 3 grams of orushed (U,Pu) $\mathrm{O}_{2}$ aintered pellets compared well with the average of $1.961 \pm 0.004$ obtained at HEDL. It was concluded that either method gave the correct result for $O / M$ ratio on aintered $(U, \mathrm{Pu})_{2}$ pellets.

\section{Development of Fuel Burnup Mengurement Mothods \\ (R. M. Abernathoy, G. M. Matiack, J.E. Rein)}

A sequential separation method has been developed ${ }^{(5)}$ that gives separate fractions containing plutonium, uranium, and neodymium for subsequent mass spectrometric measurements. This method, designed for burnup snalysis on mixed uranium-plutonium fuels, involves only two separation operations. A portion of the dissolved fuel with added lsotope spikes of ${ }^{150} \mathrm{Nd},{ }^{233} \mathrm{U}$, and ${ }^{242} \mathrm{Pu}$ is fumed with perchloric acid and transferred in 12y hydrochloric actd to a $10 \mathrm{x}$ anion exchange reati column. The effluent containing neodymium, higher tranouranics, and most other fission producto is fumed with nitric soid and transferred in a miture of $0.8 \mathrm{M} \mathrm{HNO}_{3}-90 \%$ methanol chromatographically separates the highor tranurarnics and rare earth fission products to glve a clean neodymium fraction. Plutonim is eluted from the $10 \mathrm{x}$ anton axchange resin column with a $12 \mathrm{M}$ hydrochloric acid - 0.1M ijydrolodic acid mbxture followed by wanium with 0.11 hydrochloric acid.

This method bes been used succenafully for a wide variety of experimentally irradiated FBR fuale in the 401 Program. The neodymium chromatographic separation takes about $4 \mathrm{~h}$ and is done in custom-fabriouted glans column. Modifiontions are bolng oviluted to inorense 
the speed of separation and to use "throw away" inexpensive plastic columns. These modifications consist of changes in the nitric acid strength and water-methanol composition of the loading and eluting solutions. The use of stronger nitric acid and lower methanol conteint is promising.

\section{PAPERS PRESENTED AT MEE TINGS}

1. "The Measurement of Oxygen to Heavy-Metal Atom Ratio in Unirradiated Mixed Oxide Fuel", by C. F. Metz, G. R. Waterbury and J. W. Dahlby. Presented at the "Symposium on the Analytical Chemistry of the Nuclear Fuel Cycle", sponsored by IAEA in Vienna, November 28-December 2 : 1971.

2. "Survey of Analytical Methods in the Nuclear Fuel Cycle", by C. F. Metz and G. R. Waterbury. Presented at the "Symposium on the Analytical Chemistry of the Nuclear Fuel Cycle", sponsored by IAEA in Vienna, November 28-December 2, 1971.

3. "The Determination of Non-Metallic Specification Impurities in Mixed-Oxide Reactor Fuel", by C. F. Metz and G. R. Waterbury. Presented at the "Symposium on the Analytical Chemistry of the Nuclear Fuel Cycle", sponsored by IAEA in Vienna, November 28-December 2, 1971.

4. "Status of Burnup Measurement Methodology", by J. E. Reih. Presented at the "Symposium on the Analytical Chemistry of the Nuclear Fuel Cycle", sponsored by IAEA in Vienna, November 28December 2, 1971.

5. "Sequential Ion Exchange Separaț Spectrometric Determination of ${ }^{148} \mathrm{Na}$, Uranium, and Plutonium in Mixed Oxide Fuels for Bixenup and Isotoplc Distribution Measurement", by R. M. Abernathey, G. M. Matlack, J. E. Rein. Presented by the "Symposium on the Analytical Chemistry of the Nuclear Fuel Cycle", sponsored by IAEA in Vienna, November 28-December 2, 1971.

6. "Preparation and Characterization of Reference Material for the Chemical Specification Analysis of Uranium-Plutonium Mixed Oxide Fuel and Source Materials", by J. E. Rein, R. T. Phelps, W. H. Ashley, G. R. Waterbury, C. F. Metz. Presented at the "Symposium on the Analytical Chemistry of the Nuclear Fuel Cycle", sponsored by IAEA in Vienna, November 28-December 2, 1971.

7. "A Statistically Designed Program for Sampling and Chemical Analysis of Reactor Fuel Materials", by R. K. Zeigler, G. M. Matlack, J. E. Rein, C. F. Metz. Presented at the "Symposium on the Analytical Chemistry of the Nuclear Fuel Cycle", gponsored by IAEA in Vienna, November 28. December 2, 1971.
8. "Analysis of Advanced Reactor Fuels", by G. R. Waterbury and C. F. Metz. Presented by G. R. Waterbury at the 162nd National Meeting, American Chemical Society, Washington, D. C. September 12-17, 1971.

\section{REFERENCES}

1. "Quarterly Status Report on the Advanced Plutonium Fuels Program, July 1 to September 30, 1971", LA-484:-MS, Los Alamos Sclentific Laboratory (1971), pp. 15, 16 .

2. L. Pasztor, J. Bode, and Q. Fernando, Anal. Chem. 32277 (1960).

3. S. Kitahara, H. Asahara, and T. Atoda. Rikagaku Kenkyusho Hokoku 34, 339 (1958). ORNL-Tr-1778

4. Y. P. Gokhshtein and S. V. Pankrat'eva, Zavod. Lab. 3613 (1970).

5. "Quarterly Status Report on the Advanced Plutonium Fuels Program, April 1 to June 30, 1971, ard Fifth Annual Report, FY 1971", LA-4749-MS, Los Alamos Scientific Laboratory (1971), p. 57. 
Atomic Energy Commission, Washington

Division of Reactor Development \& Technology

Assistant Director, Nuclear Safety Assistant Director, Program Analysis Assistant Director, Profect Management Assistant Director, Reactor Engineering Assistant Director, Reactor Technology Chief, Fuels and Materials Branch (3)

Chief, Fuel Engineering Branch

Chief, Fuel Recycle Branch

Division of Naval Reactors

Division of Reactor IJoensing (3)

Division of Reactor Standards (2)

Atomlc Energy Commission, Oak Ridge

Division of Technical Information Extension (100)

Atomic Energy Commission, Richland

Assistant Director Pacific Northwest Programs

Atomic Energy Commission -- RDT Site Offices

Algonne, Illinois

Idaho Falls, Idaho

Canoga Park, California

Sunnyvale, California

San Diego, California

Oak Ridge, Tennessee

Argonne National Laboratory

Director, LMFBR Program Office (2)

Director, Metallurgy Division (2)

Idaho Fallø, Idaho

EBR-II Project Irradiations Manager

Atomics International

Director, LMFBR Technology Program

P. O. Box 1449, Canoga Park

Director, LMFBR Technology Program

P. O. Bkx 309, Canoga Park

Director, Lquild Metal Engineering Centex

Atomic Power Development Associates, Detroit Head, Fuels \& Materials
Babcock \& Wilcox

Director, Nuclear Development Certer

Battelle Memorial Institute

Associate Manager

Materialo Engineering Dept.

Brookhaven National Laboratory

Manager, Metallurgy Materials Science Division

Combustion Engineering

Manager Nuclear Laboratorles

General Electric Company

Knolls Atomic Power Laboratory

Manager, Sodium Reactor Technology, Stinnyvale (2)

Director, Vallecitos Nuclear Center, Pleasanton

Gulf General Atomic, Inc.

Laboratory Assistant Director

Lawrence Radiation Laboratory

Division Leader, Inorganic Materials

NASA Lewis Research Center

Division Chief, $\mathrm{M}$ \& $\mathrm{S}$ Division

Nuclear Materials \& Equipment Corp.

Manager, Plutonium Chemistry \& Ceramics Fuels Dev.

Oak Ridge National Laboratory

Director, Metals \& Ceramics Div. (2)

Pacific Northwest Laboratory

Manager, FFTF Project (2)

FFTF Fuels Department (2)

United Nuclear Corporation

Manager, Plutonium Fuels Dept.

Westinghouse Electric Corporation

Bettis Atomic Power Laboratory

Advanced Reactor Division (2) 